Prepared in cooperation with the Public Utility District Number 1 of Lewis County, Washington, and the Washington Department of Fish and Wildlife

\title{
Behavior Patterns and Fates of Adult Steelhead, Chinook Salmon, and Coho Salmon Released into the Upper Cowlitz River Basin, 2005-09 and 2012, Washington
}

Open-File Report 2016-1144

U.S. Department of the Interior U.S. Geological Survey 
Cover: Photograph showing an October sunrise over Pompey Peak in the Upper Cowlitz River Basin, Washington. Photograph by Toby Kock, U.S. Geological Survey, October 27, 2008. 


\section{Behavior Patterns and Fates of Adult Steelhead, Chinook Salmon, and Coho Salmon Released into the Upper Cowlitz River Basin, 2005-09 and 2012, Washington}

By Tobias J. Kock, Brian K. Ekstrom, Theresa L. Liedtke, John D. Serl, and Mike Kohn

Prepared in cooperation with the Public Utility District Number 1 of Lewis County, Washington, and the Washington Department of Fish and Wildlife

Open-File Report 2016-1144

U.S. Department of the Interior

U.S. Geological Survey 


\section{U.S. Department of the Interior \\ SALLY JEWELL, Secretary}

\section{U.S. Geological Survey \\ Suzette M. Kimball, Director}

U.S. Geological Survey, Reston, Virginia: 2016

For more information on the USGS—-the Federal source for science about the Earth,

its natural and living resources, natural hazards, and the environment-visit

http://www.usgs.gov/ or call 1-888-ASK-USGS (1-888-275-8747).

For an overview of USGS information products, including maps, imagery, and publications,

visit http://store.usgs.gov.Any use of trade, firm, or product names is for descriptive purposes only and does not imply

endorsement by the U.S. Government.

Although this information product, for the most part, is in the public domain, it also may

contain copyrighted materials as noted in the text. Permission to reproduce copyrighted items

must be secured from the copyright owner.

Suggested citation:

Kock, T.J., Ekstrom, B.K., Liedtke, T.L., Serl, J.D., and Kohn, Mike, 2016, Behavior patterns and fates of adult steelhead, Chinook salmon, and coho salmon released into the upper Cowlitz River Basin, Washington, 2005-09 and 2012: U.S. Geological Survey Open-File Report 2016-1144, 36 p., http://dx.doi.org/10.3133/ofr20161144.

ISSN 2331-1258 (online) 


\section{Contents}

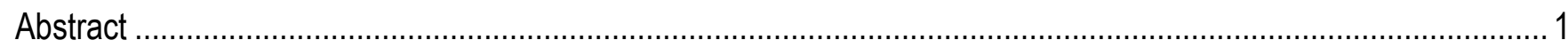

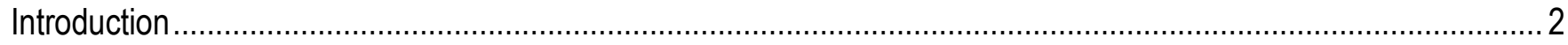

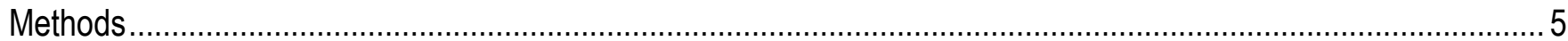

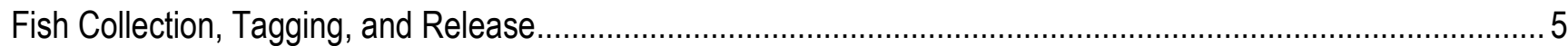

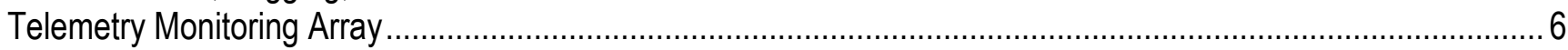

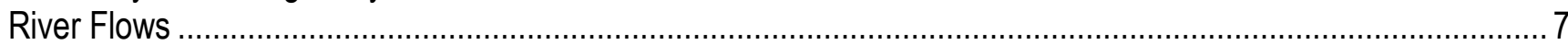

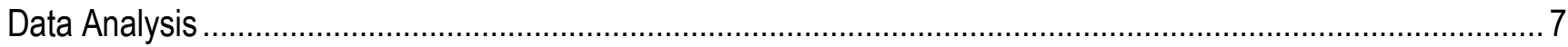

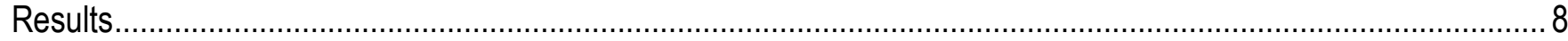

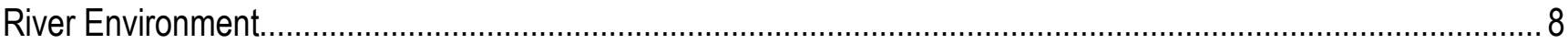

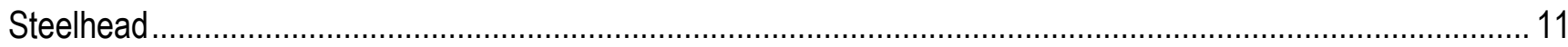

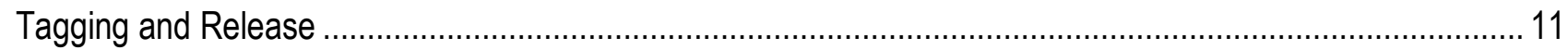

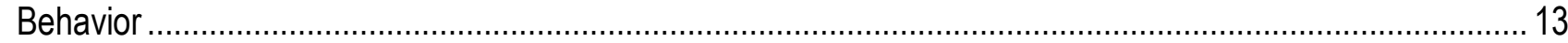

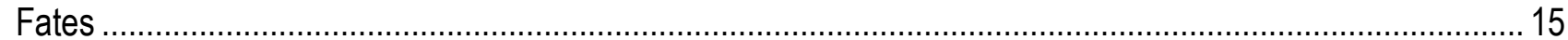

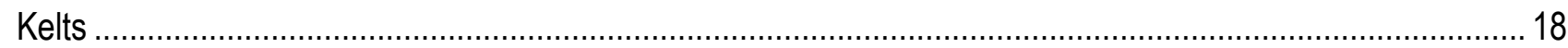

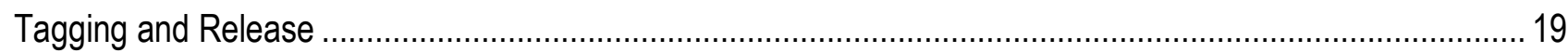

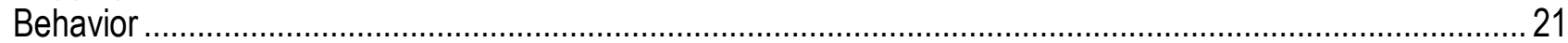

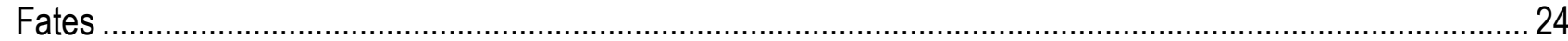

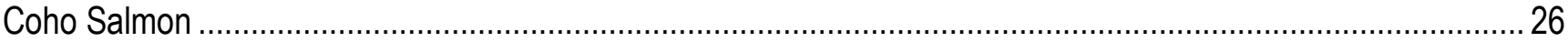

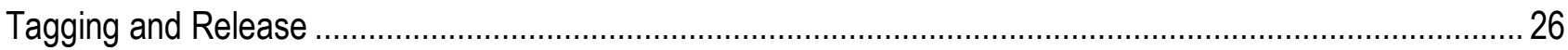

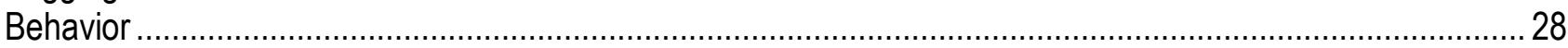

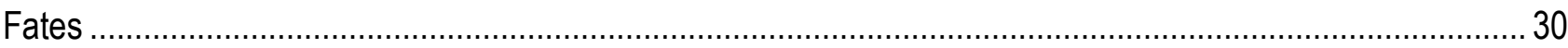

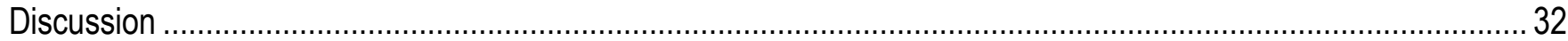

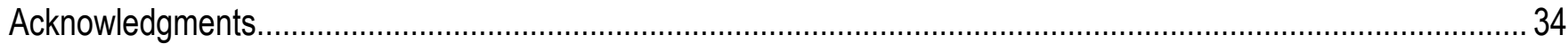

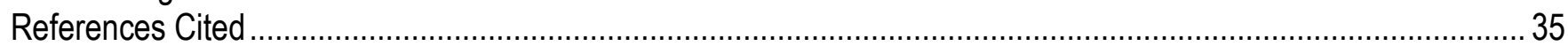




\section{Figures}

Figure 1. Map showing locations of fixed telemetry sites used during all years of the study (open circles) and some years of the study (gray circles), and places where adult salmon and steelhead were released (stars), upper Cowlitz River basin, Washington, 2005-09 and 2012.

Figure 2. Graph showing average monthly discharge in the Cowlitz and Cispus Rivers, Washington, during March-June in 2006, 2007, 2008, 2009, and 2012, when behavior of radio-tagged steelhead was being monitored.....

Figure 3. Graph showing average monthly discharge in the Cowlitz and Cispus Rivers, Washington, during April-October in 2005, 2006, 2007, and 2012, when behavior of radio-tagged Chinook salmon was being monitored.

Figure 4. Graph showing average monthly discharge in the Cowlitz and Cispus Rivers, Washington, during August-December in 2005, 2006, 2007, 2008, and 2009, when behavior of radio-tagged coho salmon was being monitored

Figure 5. Graph showing number of adult steelhead radio-tagged and released in the upper Cowlitz River Basin, 2006-09 and 2012

Figure 6. Graph showing survival distribution function of elapsed time from release of radio-tagged adult steelhead in Lake Scanewa to entry in the Cowltiz River or Cispus River, Washington, 2006-09 and 2012

Figure 7. Graphs showing relationship between monthly average discharge and percentage of fallback for monthly release groups of steelhead, Chinook salmon, and coho salmon, upper Cowlitz River Basin, Washington, 2005-09 and 2012

Figure 8. Graphs showing number of adult Chinook salmon radio-tagged and released in the upper Cowlitz River Basin, Washington, 2005-07 and 2012.

Figure 9. Graph showing survival distribution function of elapsed time from release of radio-tagged adult Chinook salmon in Lake Scanewa to entry in the Cowltiz River or Cispus River, Washington, 2005-07 and 2012.

Figure 10. Graph showing percentage of radio-tagged Chinook salmon that entered the Cowlitz or Cispus Rivers after being released into Lake Scanewa, Washington, June-October, 2005-07 and 2012.

Figure 11. Graphs showing number of adult coho salmon radio-tagged and released in the upper Cowlitz River Basin, Washington, 2005-09.

Figure 12. Graph showing survival distribution function of elapsed time from release of radio-tagged adult coho salmon in Lake Scanewa to entry in the Cowltiz River or Cispus River, Washington, 2005-09 


\section{Tables}

Table 1. Average monthly discharges in the Cowlitz and Cispus Rivers, Washington, 2005-09 and 2012 2............ 8

Table 2. Number of adult steelhead radio-tagged, released, and monitored in the upper Cowlitz River Basin, Washington, 2006-09 and 2012

Table 3. Number of adult steelhead detected in Lake Scanewa, Cowlitz River, or Cispus River following release at one of three locations in the upper Cowlitz River Basin, Washington, 2006-09 and 2012.....

Table 4. Number of adult steelhead detected in upstream and downstream reaches of the Cowlitz River and Cispus River following release in Lake Scanewa, Washington, 2006-09 and 2012

Table 5. Median elapsed time from release of radio-tagged adult steelhead to first detection in the Cowlitz River, Cispus River, or Lake Scanewa, Washington, 2006-09 and 2012

Table 6. Number of trips made by adult steelhead between Lake Scanewa and the Cowlitz River or

Cispus River, Washington, 2006-09 and 2012.

Table 7. Number of radio-tagged adult steelhead assigned to Cowlitz River, Cispus River, Lake Scanewa, and fallback fates, Washington, 2005-09 and 2012

Table 8. Percentage of adult steelhead, Chinook salmon, and coho salmon that fell back downstream of Cowlitz Falls Dam prior to spawning, Washington, 2005-09 and 2012

Table 9. Percentage of adult steelhead kelts that remained upstream of Cowlitz Falls Dam, that were collected at the dam, or that passed downstream of the dam, Washington, 2005-09 and 2012

Table 10. Number of adult Chinook salmon radio-tagged, released, and monitored in the upper Cowlitz River Basin, Washington, 2005-07 and 2012

Table 11. Number of adult Chinook salmon detected in Lake Scanewa, Cowlitz River, or the Cispus River ollowing release at one of three locations in the upper Cowlitz River Basin, Washington, 2005-07 and 2012 ....... 21

Table 12. Number of Chinook salmon that were detected in upstream and downstream reaches of the Cowlitz River or Cispus River following release in Lake Scanewa, Washington, 2005-07 and 2012.

Table 13. Median elapsed time from release of radio-tagged Chinook salmon to first detection in the

Cowlitz River, Cispus River, or Lake Scanewa, Washington, 2005-07 and 2012

Table 14. Number of trips made by Chinook salmon between Lake Scanewa and the Cowlitz River or Cispus

River, Washington, 2005-07 and 2012.

Table 15. Number of radio-tagged adult Chinook salmon assigned to Cowlitz River, Cispus River, Lake Scanewa, and fallback fates, Washington, 2005-07 and 2012.

Table 16. Number of adult coho salmon radio-tagged, released, and monitored in the upper Cowlitz River Basin, Washington, 2005-09.

Table 17. Number of adult coho salmon detected in Lake Scanewa, Cowlitz River, or Cispus River following release at one of three locations in the upper Cowlitz River Basin, Washington, 2005-09

Table 18. Number of coho salmon detected in upstream and downstream reaches of the Cowlitz River or

Cispus River following release in Lake Scanewa, Washington, 2005-09.

Table 19. Median elapsed time from release to first detection of radio-tagged coho salmon in the

Cowlitz River, Cispus River, or Lake Scanewa, Washington, 2005-09

Table 20. Number of trips made by coho salmon between Lake Scanewa and the Cowlitz River or Cispus River, Washington, 2005-09

Table 21. Number of radio-tagged adult coho salmon assigned to Cowlitz River, Cispus River, Lake Scanewa, and fallback fates, Washington, 2005-09. 


\section{Conversion Factors}

Inch/Pound to International System of Units

\begin{tabular}{lcc}
\hline Multiply & By & To obtain \\
\hline foot $(\mathrm{ft})$ & Length & meter $(\mathrm{m})$ \\
\hline & 0.3048 & \\
\hline cubic foot per second $\left(\mathrm{ft}^{3} / \mathrm{s}\right)$ & Flow rate & cubic meter per second $\left(\mathrm{m}^{3} / \mathrm{s}\right)$ \\
\hline
\end{tabular}

International System of Units to Inch/Pound

\begin{tabular}{|c|c|c|}
\hline Multiply & By & To obtain \\
\hline \multicolumn{3}{|c|}{ Length } \\
\hline centimeter $(\mathrm{cm})$ & 0.3937 & inch (in.) \\
\hline millimeter (mm) & 0.03937 & inch (in.) \\
\hline meter (m) & 3.281 & foot (ft) \\
\hline kilometer (km) & 0.6214 & mile (mi) \\
\hline
\end{tabular}

Temperature in degrees Celsius $\left({ }^{\circ} \mathrm{C}\right)$ may be converted to degrees Fahrenheit $\left({ }^{\circ} \mathrm{F}\right)$ as:

${ }^{\circ} \mathrm{F}=\left(1.8 \times{ }^{\circ} \mathrm{C}\right)+32$. 


\title{
Behavior Patterns and Fates of Adult Steelhead, Chinook Salmon, and Coho Salmon Released into the Upper Cowlitz River Basin, 2005-09 and 2012
}

\author{
By Tobias J. Kock¹, Brian K. Ekstrom¹, Theresa L. Liedtke¹, John D. Serl², and Mike Kohn ${ }^{3}$
}

\begin{abstract}
A multiyear radiotelemetry evaluation was conducted to monitor adult steelhead (Oncorhynchus mykiss), Chinook salmon (O. tshawytscha), and coho salmon (O. kisutch) behavior and movement patterns in the upper Cowlitz River Basin. Volitional passage to this area was eliminated by dam construction in the mid-1960s, and a reintroduction program began in the mid-1990s. Fish are transported around the dams using a trap-and-haul program, and adult release sites are located in Lake Scanewa, the uppermost reservoir in the system, and in the Cowlitz and Cispus Rivers. Our goal was to estimate the proportion of tagged fish that fell back downstream of Cowlitz Falls Dam before the spawning period and to determine the proportion that were present in the Cowlitz and Cispus Rivers during the spawning period. Fallback is important because Cowlitz Falls Dam does not have upstream fish passage, so fish that pass the dam are unable to move back upstream and spawn. A total of 2,051 steelhead and salmon were tagged for the study, which was conducted during 2005-09 and 2012, and 173 (8.4 percent) of these regurgitated their transmitter prior to, or shortly after release. Once these fish were removed from the dataset, the final number of fish that was monitored totaled 1,878 fish, including 647 steelhead, 770 Chinook salmon, and 461 coho salmon.

Hatchery-origin (HOR) and natural-origin (NOR) steelhead, Chinook salmon, and coho salmon behaved differently following release into Lake Scanewa. Detection records showed that the percentage of HOR fish that moved upstream and entered the Cowlitz River or Cispus River after release was relatively low (steelhead $=38$ percent; Chinook salmon $=67$ percent; coho salmon $=41$ percent) compared to NOR fish (steelhead $=84$ percent; Chinook salmon $=82$ percent; coho salmon $=76$ percent). The elapsed time from release to river entry was significantly lower for NOR fish than for HOR fish for all three species. Tagged fish entered the Cowlitz River in greater proportions than the Cispus River, regardless of origin. We found that 23-47 percent of the HOR fish entered the Cowlitz River and 12-38 percent entered the Cispus River. Similarly, 67-70 percent of the NOR fish entered the Cowlitz River and 38-66 percent entered the Cispus River. These behavioral differences translated into similar differences in fates during the spawning periods as higher percentages of tagged fish were assigned Cowlitz River fates than Cispus River fates.
\end{abstract}

\footnotetext{
${ }^{1}$ U.S. Geological Survey.

${ }^{2}$ Washington Department of Fish and Wildlife.

${ }^{3}$ Public Utility District Number 1 of Lewis County, Washington.
} 
Fallback rates were affected by fish origin and release site. Overall, 12 percent of steelhead, 19 percent of Chinook salmon, and 8 percent of coho salmon fell back downstream of Cowlitz Falls Dam prior to spawning. Fallback rates were lower for fish that were released in the Cowlitz River or the Cispus River than for reservoir-released fish, but statistical comparisons were not robust because of small sample sizes at the river release sites. Fallback rates for fish released at the river release sites were 10 percent lower for steelhead, 4 percent lower for Chinook salmon, and 9 percent lower for coho salmon than for reservoir-released fish. However, fallback rates also were different between HOR and NOR fish. Fallback rates were significantly higher for HOR reservoir-released fish than for NOR reservoir-released fish.

This study provided data that were insightful for understanding behavior and movement patterns in the upper Cowlitz River Basin and yielded estimates of fallback rates and fish fates that may be useful for fishery managers in the years to come. Studies from other systems have shown that factors such as prespawn mortality and fallback have resulted in substantial losses to spawning populations where trap-and-haul programs are being used as a restoration tool. Future research in the upper Cowlitz River Basin may use additional telemetry studies, genetic analyses, and spawning ground surveys to provide answers for new questions and to continue to monitor the progress of the reintroduction effort.

\section{Introduction}

Many of the dams that were constructed in the Pacific Northwest during the 20th century failed to provide upstream fish passage, which eliminated access to important spawning areas for numerous anadromous salmonid (Oncorhynchus spp.) populations. By the 1990s, many of these populations had declined to levels that necessitated listing as threatened or endangered under the U.S. Endangered Species Act (National Marine Fisheries Service, 1999). Efforts to restore salmon runs to areas blocked by dams have included the implementation of trap-and-haul programs, installation of fish passage devices, population supplementation and reintroduction, and dam removal (Bryant and others, 1999; Pearsons and Temple, 2007; Brenkman and others, 2008; Anderson and others, 2014). Trap-and-haul programs are common because they do not require dam modifications (which can be expensive), yet still provide access for anadromous fish into areas that are blocked.

In the Cowlitz River, Washington, volitional fish passage was eliminated when Mayfield Dam and Mossyrock Dam were constructed (fig. 1) in the 1960s. Mayfield Dam was constructed in 1963 and included adult fish passage facilities, but these were not used after 1968 when Mossyrock Dam was completed. Mossyrock Dam is the tallest dam in Washington State, and its height created conditions that eliminated volitional passage for upstream and downstream fish migrants. Functional fish ladders were not possible given the height of the dam, and downstream passage was eliminated because of the size and depth of Riffe Lake (fig. 1) and depth of turbines. Two other dams are located on the Cowlitz River, and these dams provided the opportunity to implement a trap-and-haul program in 1996 that reintroduced anadromous salmonids to the upper Cowlitz River Basin. The Barrier Dam, located $4 \mathrm{~km}$ downstream of Mayfield Dam, was designed to stop upstream migrants at the location where the Cowlitz Salmon Hatchery's adult fish ladder entrance is located. Adult salmon encounter the Barrier Dam as they move upstream and then enter the fish ladder and ascend to a trap where they can be sorted and retained for propagation at the hatchery, or loaded onto trucks and transported upstream. Cowlitz Falls Dam is located $38 \mathrm{~km}$ upstream of Mossyrock Dam and was designed to be easily retrofitted to collect downstream migrants after it was completed in 1994, when funding became available (fig. 1). 

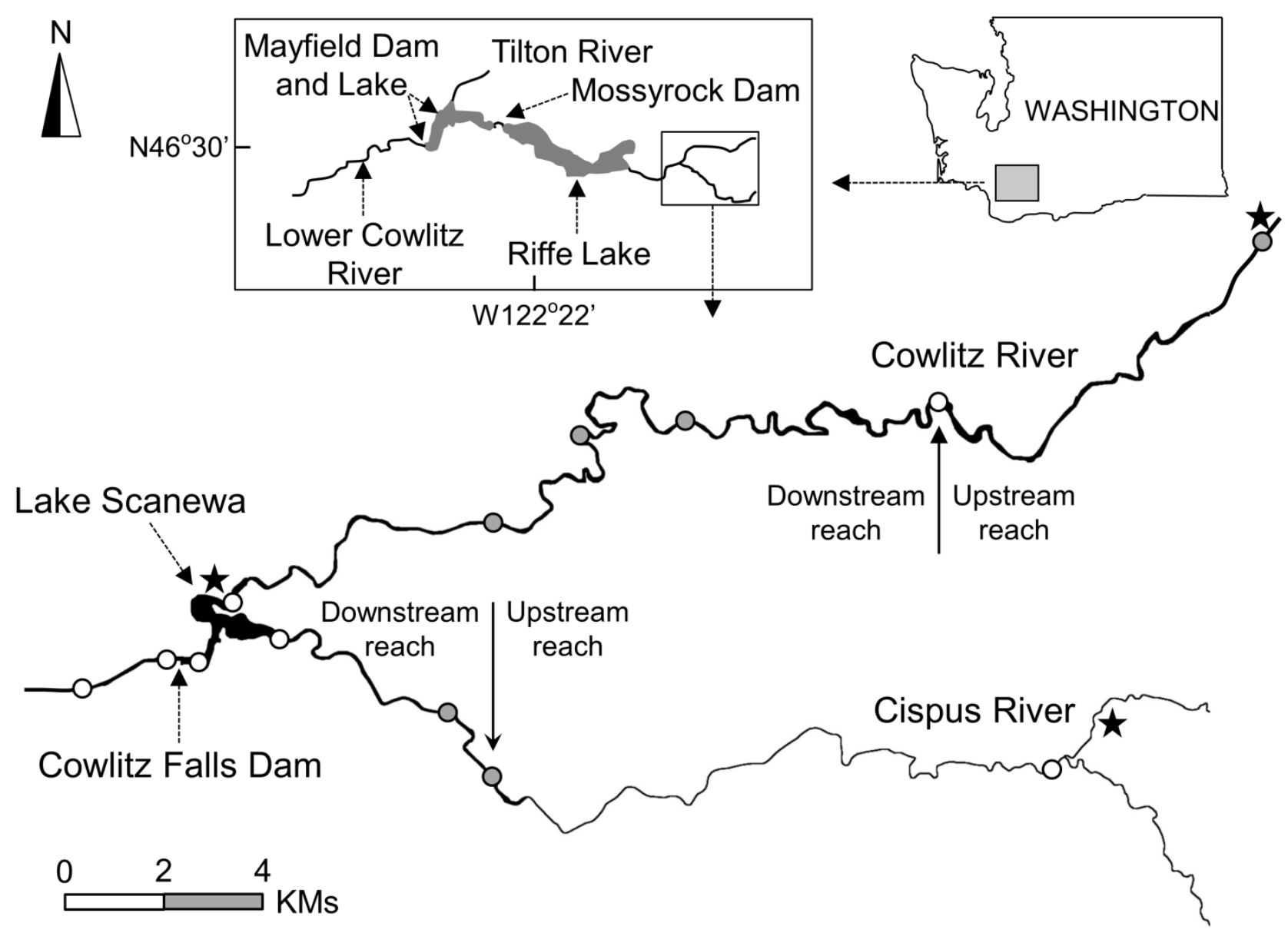

Figure 1. Map showing locations of fixed telemetry sites used during all years of the study (open circles) and some years of the study (gray circles), and places where adult salmon and steelhead were released (stars), upper Cowlitz River basin, Washington, 2005-09 and 2012. Solid line arrows show the locations that delineated the boundaries for the upstream and downstream reaches in each river. 
The trap-and-haul program has been the cornerstone of efforts to restore steelhead (O. mykiss), spring and fall Chinook salmon (O. tshawytscha), and coho salmon (O. kisutch) populations in the upper Cowlitz River, Washington, since 1996. Adult salmon and steelhead are collected at the Cowlitz Salmon Hatchery and transported upstream to release sites on the Tilton, Cowlitz, and Cispus Rivers (fig. 1). The primary release site in the upper Cowlitz River is located in Lake Scanewa, the reservoir created when Cowlitz Falls Dam was constructed. The confluence of the Cowlitz and Cispus Rivers is near the middle of Lake Scanewa (fig. 1), which provides the opportunity for fish to self-select one of these rivers for spawning after being released at the Lake Scanewa release site. Providing a site that allowed these adult fish to self-select a river, possibly the river of its origin, was among the highest priorities for the committee responsible for reintroducing anadromy to the upper Cowlitz River Basin. Two additional release sites that were added at a later date are located upstream of Lake Scanewa. One is located on the Cowlitz River near the town of Packwood, Washington, $55 \mathrm{~km}$ upstream of the Lake Scanewa release site (fig. 1). The other site is located on the Cispus River near the mouth of Yellowjacket Creek, $25 \mathrm{~km}$ upstream of the Lake Scanewa release site (fig. 1). These sites are typically used during summer when water temperatures in Lake Scanewa exceed $20^{\circ} \mathrm{C}$. The trap-and-haul program has returned anadromous salmonids to $322 \mathrm{~km}$ of stream habitat in the upper Cowlitz River Basin, and juvenile salmonid collection efforts at Cowlitz Falls Dam have indicated that adult salmon and steelhead are successfully spawning and producing progeny that out-migrate from the upper basin. However, little is known about behavior patterns, spawning locations, and fates of adult salmon and steelhead following release.

Trap-and-haul programs are in-place at numerous locations in the Pacific Northwest, but only a small number of studies have been conducted to evaluate the success of these efforts. The information that is available has shown that prespawn mortality rates can be high in some cases, and factors such as sex, origin, and release timing can affect the reproductive success of transported fish. For example, in the Willamette River Basin during 2009-14, average prespawn mortality rates for female spring Chinook salmon were greater than 60 percent in Fall Creek and 30 percent in the North Fork Middle Fork Willamette River (Naughton and others, 2015). During 2008-11, Sard and others (2015) evaluated a trap-and-haul program in the South Fork McKenzie River, Oregon, and showed that reproductive success of Chinook salmon was affected by sex, origin, and release date. In that study, male salmon were less fit than female salmon, and hatchery-origin (HOR) male Chinook salmon were less fit than natural-origin (NOR) male Chinook salmon. Additionally, fish that were transported early in the season had greater reproductive success than fish that were transported later in the season. Given these findings, evaluation of the Cowlitz River trap-and-haul program is important to understand fish behavior patterns following release in the upper Cowlitz River Basin.

A multi-year telemetry study was conducted during 2005-09 and 2012 to describe post-release behaviors and fates of adult salmon and steelhead in areas located upstream of Cowlitz Falls Dam. This study was conducted cooperatively with the Washington Department of Fish and Wildlife and the Public Utility District No. 1 of Lewis County, Washington. Our primary objective was to determine if tagged fish moved into mainstem or tributary habitats in the upper Cowlitz and Cispus Rivers during spawning periods. This would be a favorable outcome for transported fish because these areas contain habitat suitable for spawning in the upper basin. Alternatively, fish could remain in Lake Scanewa, or move downstream and pass Cowlitz Falls Dam prior to spawning. These outcomes would be unfavorable because Lake Scanewa contains very little suitable spawning habitat for adult salmon and steelhead, and Cowlitz Falls Dam does not have an adult fish ladder, so fish that pass downstream of the dam prior to spawning are lost to the population. To provide information about differences in fish origin and release site locations, our study included releases of HOR and NOR fish, and releases occurred at each of the three release sites. 


\section{Methods}

\section{Fish Collection, Tagging, and Release}

Adult salmon and steelhead were collected for tagging at the Cowlitz Salmon Hatchery (rkm 113.7) downstream of Mayfield Dam on the lower Cowlitz River (fig. 1). The fish trap at the hatchery operates continuously during periods when adult salmon are migrating. Fish are handled and sorted during weekdays by staff from Tacoma Power. Fish were anesthetized to facilitate the sorting process. Two methods of anesthesia were used during our study - a carbon dioxide bath was used during 200509, and electrosedation (Model EA-1000B, Smith-Root, Inc., Vancouver, Washington) was used in 2012. An automatic crowder was located inside the fish trap, and an exit chute was located near the top of the trap that led to the area where anesthesia was administered. The crowder was used to force groups of fish (20-50 fish/group) into the exit chute for a batch application of anesthesia. The carbon dioxide bath was created inside an aluminum fish holding tank that was filled with fresh river water at the start of each day. Carbon dioxide was then bubbled into the bath during the rest of the day along with a small volume of fresh river water to minimize temperature increases in the tank. Each batch of fish was submerged in the carbon dioxide bath until they were inactive and then processed. The electrosedation system was commissioned in 2010 as part of a series of upgrades to the Cowlitz Salmon Hatchery. Groups of fish were crowded into a large holding basket and electrosedation was applied for approximately $30 \mathrm{~s}$, after which fish were immobile and ready for sorting. The fish sorting process was identical, regardless of the anesthesia method used. Fish were sorted by species and origin and then moved into one of eight concrete holding tanks, where they could be transferred to the hatchery for spawning or loaded onto fish hauling trucks and transported to upstream release sites. Tagging occurred after sorting but before fish were transferred to the holding tanks.

The fish tagging process was similar during all years of the study. We collected the following data for each fish that was tagged - species, origin (natural or hatchery), sex (visually assessed), and fork length (centimeters). Once these data were collected, a radio transmitter was gastrically implanted using methods described by Keefer and others (2004). Transmitter technologies improved over the course of the study period, so we used smaller transmitters that had longer operating life later in the

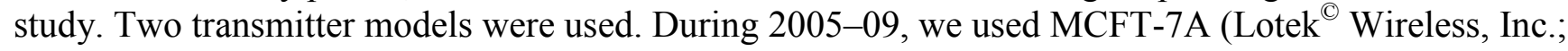
Newmarket, Ontario, Canada) transmitters that were $83 \times 16 \mathrm{~mm}$ and weighed $13 \mathrm{~g}$ in water. During 2012, we used MCFT-3EM transmitters (Lotek ${ }^{\circledR}$ Wireless, Inc.; Newmarket, Ontario, Canada) that were $53 \times 12 \mathrm{~mm}$ and weighed $4.3 \mathrm{~g}$ in water. All transmitters emitted a signal every $5 \mathrm{~s}$, and the estimated operating life was $296 \mathrm{~d}$ for the MCFT-7A transmitters and $528 \mathrm{~d}$ for the MCFT-3EM transmitters. A single band of silicon tubing (approximately $1-\mathrm{cm}$ long) was placed around the lower portion of each transmitter to decrease the likelihood that transmitters were regurgitated (Keefer and others, 2004). Following tagging, each fish was transferred to a concrete holding tank where they were held (along with untagged fish) overnight to recover from the trapping, sorting, and tagging process. 
On each release day, groups of fish were loaded onto fish hauling trucks for transport to the upper Cowlitz River Basin. The loading process consisted of a water-to-water transfer from the holding tank to the fish hauling truck. Transport trucks hauled approximately 130 adult salmon or steelhead in each load, and tagged fish were transported with untagged fish. Transport time from the Cowlitz Salmon Hatchery to the Lake Scanewa release site was approximately $45 \mathrm{~min}$. Transport from the Cowlitz Salmon Hatchery to the Cowlitz River and Cispus River release sites was approximately 90 min. Releases normally occurred in the morning between 09:00 a.m. and 11:00 a.m. Fish were released directly from the transport truck into the river at the Lake Scanewa and Cispus River release sites using a 1.0-m-long flume that minimized the drop from the truck to the river. At the Cowlitz River release site, fish were released through a 3.0-m-long plastic pipe $(30.5 \mathrm{~cm}$ diameter $)$ that transported water and fish from the truck to the river.

\section{Telemetry Monitoring Array}

A series of fixed telemetry monitoring sites (hereinafter "fixed sites") were deployed to detect tagged fish as they moved throughout the study area. Seven fixed sites were used during all years of the study and several other sites were used during 1 or more of the years to determine when fish were in the Cowlitz River, in the Cispus River, in Lake Scanewa, or when they passed downstream of Cowlitz Falls Dam. The seven primary fixed sites were located at the following locations:

- on the Cowlitz River at rkm 179;

- in the Cowlitz Arm of Lake Scanewa at rkm 146;

- on the Cispus River at rkm 25;

- in the Cispus Arm of Lake Scanewa at rkm 2;

- in the forebay of Cowlitz Falls Dam at rkm 142;

- in the tailrace of Cowlitz Falls Dam at rkm 141; and

- downstream of Cowlitz Falls Dam at the head of Riffe Lake at rkm 137 (fig. 1).

The remaining fixed site locations varied among years due to changes in access and improvements in our understanding of fish movement patterns. The locations of these fixed sites allowed us to collect additional information on fish movement patterns between the primary sites. All fixed site locations that were used during the study are presented in figure 1. Each fixed site contained a telemetry receiver (Model SRX-600; Lotek $^{\mathbb{C}}$ Wireless, Inc., Newmarket, Ontario, Canada) that was connected to one or two Yagi antennas. Power was provided by a $12-\mathrm{V}$ battery that was recharged by a solar panel. Based on the locations of the fixed sites, we divided the Cowlitz and Cispus Rivers into downstream and upstream regions to provide additional information on fish-use patterns (fig. 1). The downstream region of the Cowlitz River was approximately 33-rkm long and included the area between rkm 179 and 146. The upstream region of the Cowlitz River included the area located upstream of rkm 179. The downstream region of the Cispus River was approximately 6-rkm long and included the area between rkm 8 and 2. The upstream region of the Cispus River included the area located upstream of rkm 8 (fig. 1)

Data from fixed site detections were supplemented with mobile tracking detections during most years of the study. Mobile tracking took place at least one time per week during 2005, 2006, 2007, and 2008. These efforts were primarily conducted using a vehicle to drive slowly along roads that bordered the rivers and reservoir in the study area while monitoring a telemetry receiver. Additional irregular mobile tracking efforts during the study were conducted using an inflatable raft, and a helicopter was used on two occasions. 


\section{River Flows}

River flows in the upper Cowlitz River Basin are monitored by four streamgages operated by the U.S. Geological Survey. Two streamgages are located on the Cowlitz River, upstream of Lake Scanewa near the towns of Packwood (14226500) and Randle (14231000). The third streamgage is located on the Cispus River near the mouth of Yellowjacket Creek (14231900). The fourth streamgage is located at Cowlitz Falls Dam and is known as the Kosmos streamgage (14233500). Discharge data from the Randle, Cispus, and Kosmos streamgages are highly correlated for the following reasons - the Cowlitz and Cispus Rivers respond fairly similarly to rainfall and snowmelt events given their proximity to each other; and discharge at the Kosmos streamgage is essentially the sum of discharge at the Randle and Yellowjacket Creek streamgages. Therefore, in this report, we only present discharge data from the Kosmos streamgage.

\section{Data Analysis}

Fish detection records were examined to describe behavior patterns and determine fates of individual tagged fish. To accomplish this, we divided the study area into four regions and identified dates that were used to demarcate the onset of the spawning period for each species that we studied. The four regions were (1) the Cowlitz River, which included the mainstem Cowlitz River and its tributaries located upstream of the fixed site at rkm 146; (2) the Cispus River, which included the mainstem Cispus River and its tributaries located upstream of the fixed site at rkm 2; (3) Lake Scanewa, which was bounded on the downstream end at Cowlitz Falls Dam and at the upstream ends at rkm 146 on the Cowlitz River and at rkm 2 on the Cispus River; and (4) Riffe Lake, which was defined as anything located downstream of Cowlitz Falls Dam. Dates used to demarcate the onset of spawning for each species were March 15 for steelhead, August 1 for spring Chinook salmon (hereinafter "Chinook salmon"), and October 24 for coho salmon. These dates were established based on the run timing of each species and from observations made during redd surveys by the Washington Department of Fish and Wildlife (Serl and Morrill, 2010). These dates were used to differentiate between fish behaviors and fates that occurred during the prespawning period, or after spawning began.

We identified the fate of each fish to estimate the proportion (expressed as a percentage) of fish that were in the Cowlitz River or Cispus River during the spawning period, that remained in Lake Scanewa during the spawning period, or that fell back into Riffe Lake prior to spawning. Fish were assigned Cowlitz River or Cispus River fates if they were last detected in either river prior to the spawning period, or if they were detected in either river during the spawning period. In some cases, Chinook and coho salmon moved downstream after the onset of the spawning period, and this behavior was common for steelhead, which are iteroparous. To account for this, we established a minimum time criterion of $4 \mathrm{~d}$, during which a tagged fish had to reside in one of the rivers after the onset of the spawning period. The minimum time criterion was established primarily for steelhead because Chinook and coho salmon remained in their tributary after spawning occurred. Examination of the telemetry records of steelhead showed that some tagged fish spent $4 \mathrm{~d}$ in a tributary before moving downstream and out of the system. If a tagged fish was present in one of the rivers for at least $4 \mathrm{~d}$ after spawning began, it was assigned the fate of that river, unless it moved back upstream and entered one of the rivers for at least 4 more days. If a tagged fish was in one of the rivers for less than $4 \mathrm{~d}$ after the onset of spawning, it was not assigned to that fate. Fish were assigned a reservoir fate if they were last detected in Lake Scanewa prior to the onset of the spawning period, or if they spent less than $4 \mathrm{~d}$ in one of the rivers before moving downstream and remaining in the reservoir after the onset of the spawning period. Fish were assigned a fallback fate if they were detected downstream of Cowlitz Falls Dam prior to the onset of the spawning period. For steelhead, we also assigned a second fate to estimate the proportion 
(expressed as a percentage) of fish that moved downstream as kelts. This second fate included four possible outcomes - (1) fish that did not move downstream after spawning; (2) fish that moved downstream after spawning but remained in Lake Scanewa; (3) fish that moved downstream after spawning and were collected at the Cowlitz Falls fish facility; and (4) fish that moved downstream after spawning and passed Cowlitz Falls Dam.

We used a Chi-squared test of independence to assess statistical differences between groups of fish when evaluating most metrics that described fish behavior patterns or fates (Sokal and Rohlf, 1996). We also used an event-time analysis (Allison, 1995) to compare reservoir residence times and upstream movements by HOR and NOR fish following release into Lake Scanewa. Event times were censored for fish that did not move upstream and censoring was set to $40 \mathrm{~d}$ for steelhead, $140 \mathrm{~d}$ for Chinook salmon, and $80 \mathrm{~d}$ for coho salmon. These censoring periods were based on maximum expected time that a given fish would spend upstream of Cowlitz Falls Dam prior to the onset of the spawning period. River residence times were calculated as the elapsed time from release in the Cowlitz River or Cispus River to first detection in Lake Scanewa. We used $t$-tests to assess statistical differences in fish size metrics (Sokal and Rohlf, 1996). Our analyses focused on describing fish behavior patterns and fates and did not consider how these metrics were affected by covariates such as discharge or water temperature. Those analyses are likely to be completed at a later date using approaches described in Kock and others (2016).

\section{Results}

\section{River Environment}

Discharge in the upper Cowlitz River Basin is largely influenced by rainfall and snowmelt events. Rainfall is common during November-March, when monthly discharge is typically in the 2,500-6,000 $\mathrm{ft}^{3} / \mathrm{s}$ range (table 1). Snowmelt generally occurs during April-June when river flows peak and monthly discharges greater than $7,000 \mathrm{ft}^{3} / \mathrm{s}$ are common. Low-flow periods occur during August, September, and October when monthly discharge generally is less than $1,500 \mathrm{ft}^{3} / \mathrm{s}$ (table 1). During our study period, annual discharge was lowest during 2005 when discharge was less than $3,000 \mathrm{ft}^{3} / \mathrm{s}$ in 7 of the 12 months of the year. Conversely, annual discharge was highest during 2012, when monthly discharge exceeded $6,000 \mathrm{ft}^{3} / \mathrm{s}$ during 7 of the 12 months of the year (table 1 ).

Table 1. Average monthly discharges in the Cowlitz and Cispus Rivers, Washington, 2005-09 and 2012.

[Data from U.S. Geological Survey streamgage Cowlitz River near Kosmos, Washington (14233500). SD, standard deviation]

\begin{tabular}{lllllllllllllr}
\hline \multirow{2}{*}{ Year } & \multicolumn{10}{c}{ Average monthly discharges, in cubic feet per second } \\
& \multicolumn{1}{c}{ Jan } & Feb & Mar & Apr & May & June & July & Aug & Sept & Oct & Nov & Dec \\
\hline 2005 & 5,452 & 2,276 & 2,644 & 5,273 & 5,018 & 2,835 & 1,771 & 1,148 & 926 & 1,226 & 4,017 & 5,350 \\
2006 & 10,552 & 5,571 & 2,702 & 4,589 & 8,340 & 7,051 & 2,809 & 1,352 & 1,013 & 734 & 12,020 & 7,214 \\
2007 & 5,589 & 5,173 & 9,142 & 4,989 & 5,903 & 4,691 & 2,325 & 1,228 & 996 & 1,501 & 2,277 & 5,794 \\
2008 & 3,047 & 2,741 & 3,582 & 3,019 & 12,265 & 10,445 & 5,716 & 2,108 & 1,405 & 1,116 & 5,494 & 2,437 \\
2009 & 9,410 & 2,739 & 2,897 & 5,424 & 9,538 & 7,026 & 2,468 & 1,272 & 1,112 & 1,558 & 5,160 & 4,267 \\
2012 & 6,170 & 6,389 & 5,262 & 8,210 & 9,015 & 8,091 & 5,271 & 1,998 & 1,232 & 2,839 & 6,855 & 6,164 \\
Mean & 6,703 & 4,148 & 4,372 & 5,251 & 8,346 & 6,690 & 3,393 & 1,518 & 1,114 & 1,496 & 5,971 & 5,204 \\
SD & 2,279 & 1,764 & 2,535 & 1,690 & 2,618 & 2,652 & 1,667 & 421 & 178 & 722 & 3,338 & 1,665 \\
\hline
\end{tabular}


Adult steelhead are present in the upper Cowlitz River Basin during March-June each year. In the years we monitored steelhead, discharge generally was lowest during March and highest during May (fig. 2). However, discharge patterns during 2007 were unusual because discharge was highest during March and then decreased to around 5,000 ft $3 / \mathrm{s}$ during April-June. Discharge during 2012 was highest during most months in the years we monitored steelhead, although average monthly discharges in May and June 2008 exceeded 10,000 $\mathrm{ft}^{3} / \mathrm{s}$ (fig. 2).

Adult Chinook salmon spend several months in the upper Cowlitz River Basin each year. Trapand-haul for these fish typically begins in April, and spawning occurs during August-October, so fish are exposed to a wide range of discharge conditions during the prespawning and spawning periods. Many Chinook salmon are released into the upper Cowlitz River Basin prior to, or during, peak periods in May, and they reside in the system throughout summer when discharge is decreasing to the lowest levels of the year (fig. 3). During our study period, discharge was highest during 2012 and lowest during 2005 (fig. 3). During 2006, discharge was relatively high during May and June (7,000 ft $3 / \mathrm{s}$ or greater), and 2007 discharge was similar to 2005 discharge (fig. 3).

Adult coho salmon are transported and released into the upper Cowlitz River Basin during autumn and winter. In the years we monitored coho salmon, river discharges were low during AugustOctober, then highly variable during November-March (fig. 4). Discharge when coho salmon were present in the system generally was highest during 2006 and lowest during late-autumn and winter 2008 (fig. 4). Average monthly discharge ranged from less than $1,000 \mathrm{ft}^{3} / \mathrm{s}$ to greater than $12,000 \mathrm{ft}^{3} / \mathrm{s}$ when coho salmon were being monitored (fig. 4).

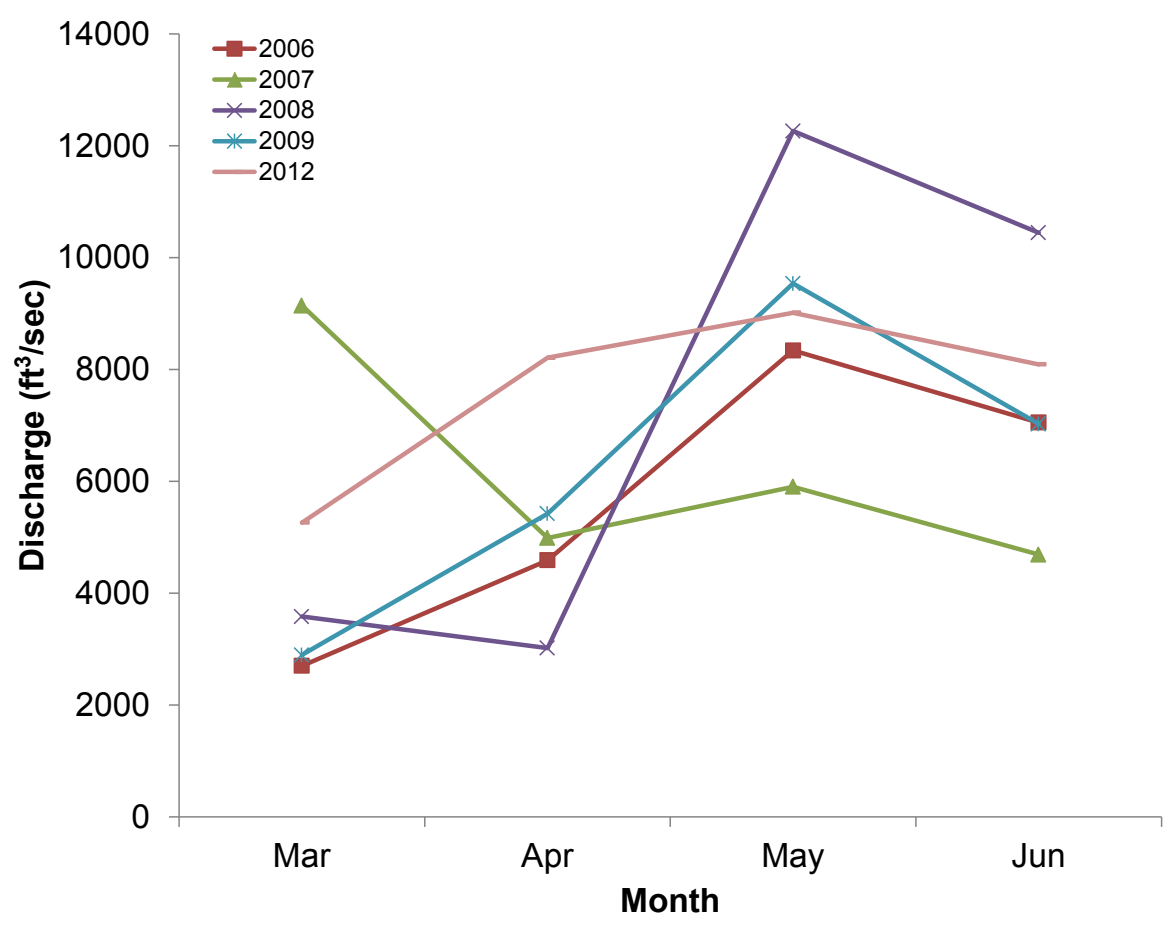

Figure 2. Graph showing average monthly discharge in the Cowlitz and Cispus Rivers, Washington, during March-June in 2006, 2007, 2008, 2009, and 2012, when behavior of radio-tagged steelhead was being monitored. Data from USGS streamgage on the Cowlitz River near Kosmos, Washington (14233500). 


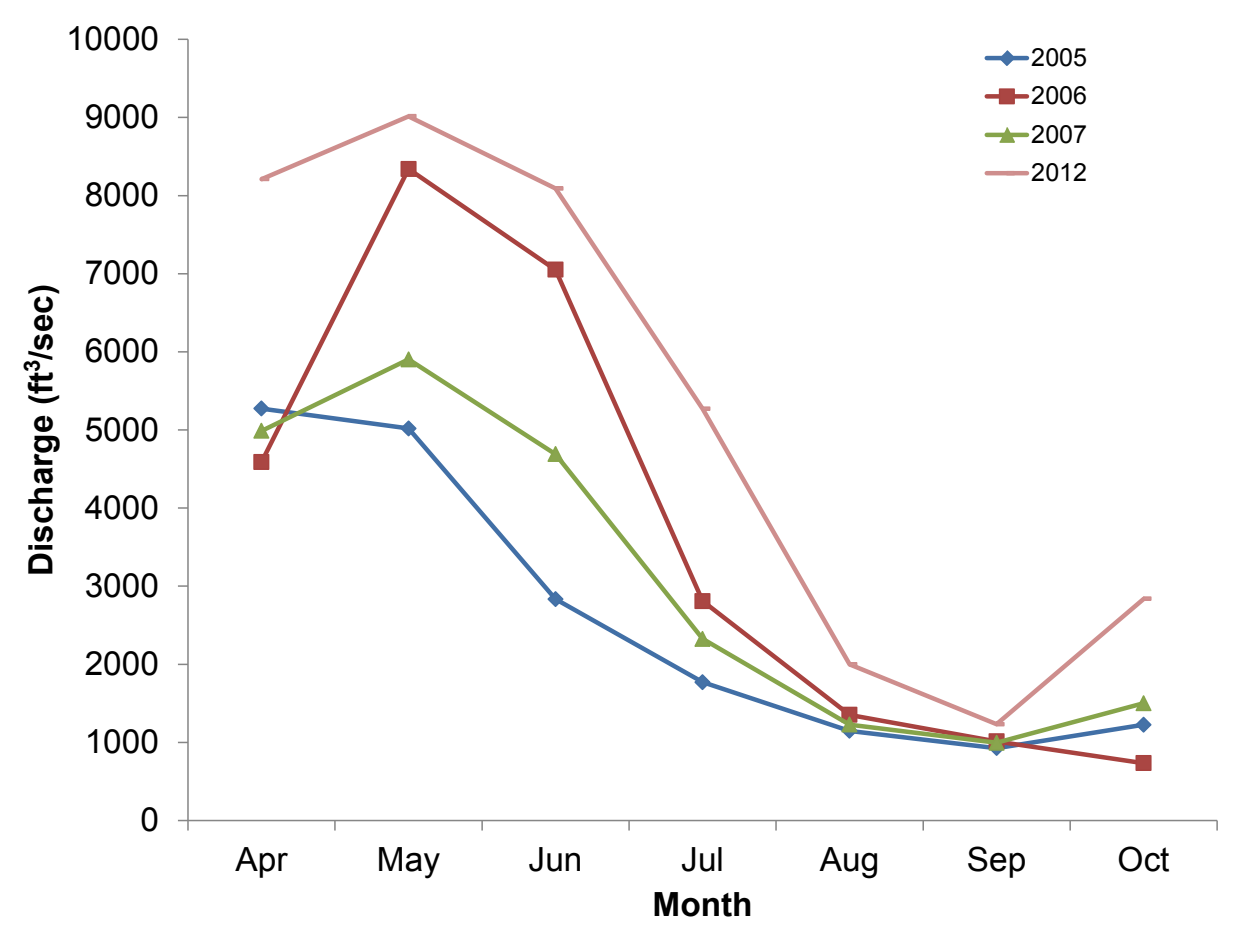

Figure 3. Graph showing average monthly discharge in the Cowlitz and Cispus Rivers, Washington, during AprilOctober in 2005, 2006, 2007, and 2012, when behavior of radio-tagged Chinook salmon was being monitored. Data from USGS streamgage on the Cowlitz River near Kosmos, Washington (14233500).

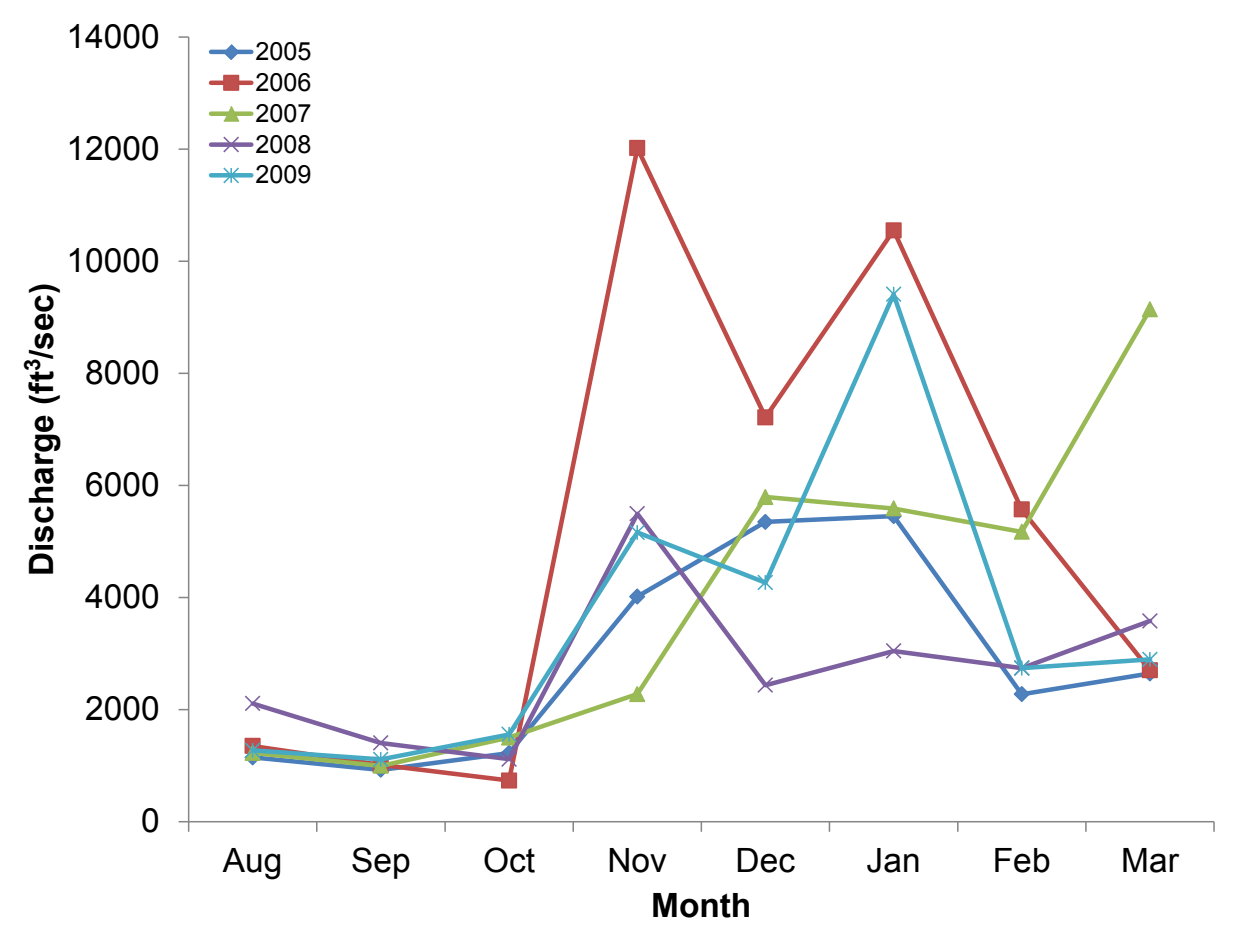

Figure 4. Graph showing average monthly discharge in the Cowlitz and Cispus Rivers, Washington, during August-December in 2005, 2006, 2007, 2008, and 2009, when behavior of radio-tagged coho salmon was being monitored. Data from USGS streamgage on the Cowlitz River near Kosmos, Washington (14233500). 


\section{Steelhead}

\section{Tagging and Release}

A total of 719 steelhead were radio-tagged for the study, but 72 fish (10.0 percent) regurgitated their transmitter prior to, or shortly after, release (table 2). The final tagged population included 647 fish, and these were split almost evenly between males (366 fish; 51 percent) and females (353 fish; 49 percent). The average length of tagged females was $71.4 \mathrm{~cm}$ and the average length of tagged males was $70.3 \mathrm{~cm}$, which was nearly statistically different $(t=1.86, P=0.06)$. The tagged population contained slightly more HOR steelhead (387 fish; 53.8 percent) than NOR steelhead (332 fish; 46.2 percent). Natural-origin steelhead were larger (average length $=72.6 \mathrm{~cm}$ ) than HOR steelhead (average length $=$ $69.2 \mathrm{~cm} ; t=-5.82, P<0.0001$ ). Most of the tagged fish were released into Lake Scanewa (505 fish; 78.1 percent), and the remaining fish were released into the Cowlitz River (63 fish; 9.7 percent) or the Cispus River (79 fish; 12.2 percent; table 2). Fish were released during March, April, and May (fig. 5).

Table 2. Number of adult steelhead radio-tagged, released, and monitored in the upper Cowlitz River Basin, Washington, 2006-09 and 2012.

[Data include hatchery-origin (HOR) and natural-origin fish (NOR). Numbers in parentheses are tagged fish that regurgitated their transmitter during transport or at the release site]

\begin{tabular}{l|cc|cc|cc}
\hline \multirow{2}{*}{ Year } & \multicolumn{2}{c|}{ Lake Scanewa release site } & \multicolumn{2}{c|}{ Cowlitz River release site } & \multicolumn{2}{c}{ Cispus River release site } \\
\cline { 2 - 7 } & HOR & NOR & HOR & NOR & HOR & NOR \\
\hline 2006 & $46(18)$ & $90(12)$ & 0 & 0 & $16(1)$ & 0 \\
2007 & $34(6)$ & $35(4)$ & 0 & 0 & 0 & 0 \\
2008 & $33(5)$ & $73(6)$ & 42 & 0 & $38(1)$ & 0 \\
2009 & $132(16)$ & $15(2)$ & 0 & 0 & 0 & 0 \\
2012 & 0 & $43(1)$ & 0 & 21 & 0 & 25 \\
\hline Total & 245 & 260 & 42 & 21 & 54 & 25 \\
\hline
\end{tabular}




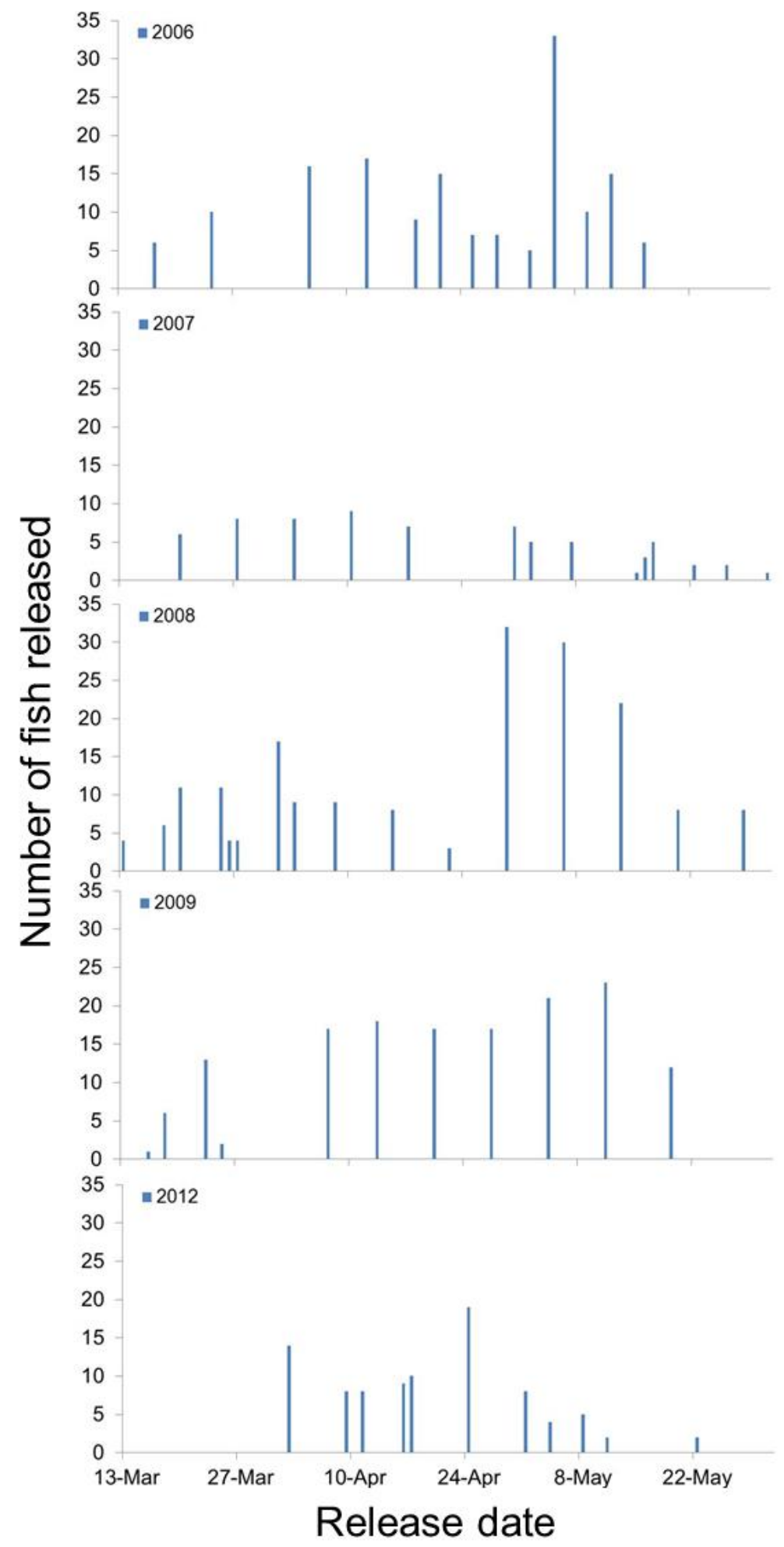

Figure 5. Graph showing number of adult steelhead radio-tagged and released in the upper Cowlitz River Basin, 2006-09 and 2012. 


\section{Behavior}

There were differences in upstream dispersal patterns and in reservoir residence times prior to dispersal between HOR and NOR steelhead that were released into Lake Scanewa. We found that 38 percent of the reservoir-released HOR steelhead moved upstream and entered the Cowlitz River or the Cispus River compared to 84 percent of the NOR steelhead. Median elapsed time from release in the reservoir to first detection in one of the rivers was $2.5 \mathrm{~d}$ for HOR steelhead and $0.9 \mathrm{~d}$ for NOR steelhead. Event-time analysis showed that there were statistical differences in upstream movement patterns between HOR and NOR steelhead (Wilcoxon test $\chi^{2}=151.4, P<0.0001$; fig. 6 ). The percentage of tagged fish entering the Cowlitz River was greater than the percentage of tagged fish entering the Cispus River and this pattern did not vary by fish origin (tables 3 and 4). We found that 67 percent of the reservoir-released NOR steelhead entered the Cowlitz River but only 30 percent of the fish moved into the upstream reach of the river (table 4). By comparison, 23 percent of the HOR steelhead entered the Cowlitz River and 8 percent entered the upstream reach. River entry events were lower for the Cispus River. Twenty-eight percent of the NOR steelhead and 18 percent of the HOR steelhead entered the river and the percentage of reservoir-released fish that entered the upper reach was low (15 and 7 percent, respectively; table 4). The median elapsed time from release to first detection in either river decreased, with increasing release month for HOR and NOR steelhead (table 5).

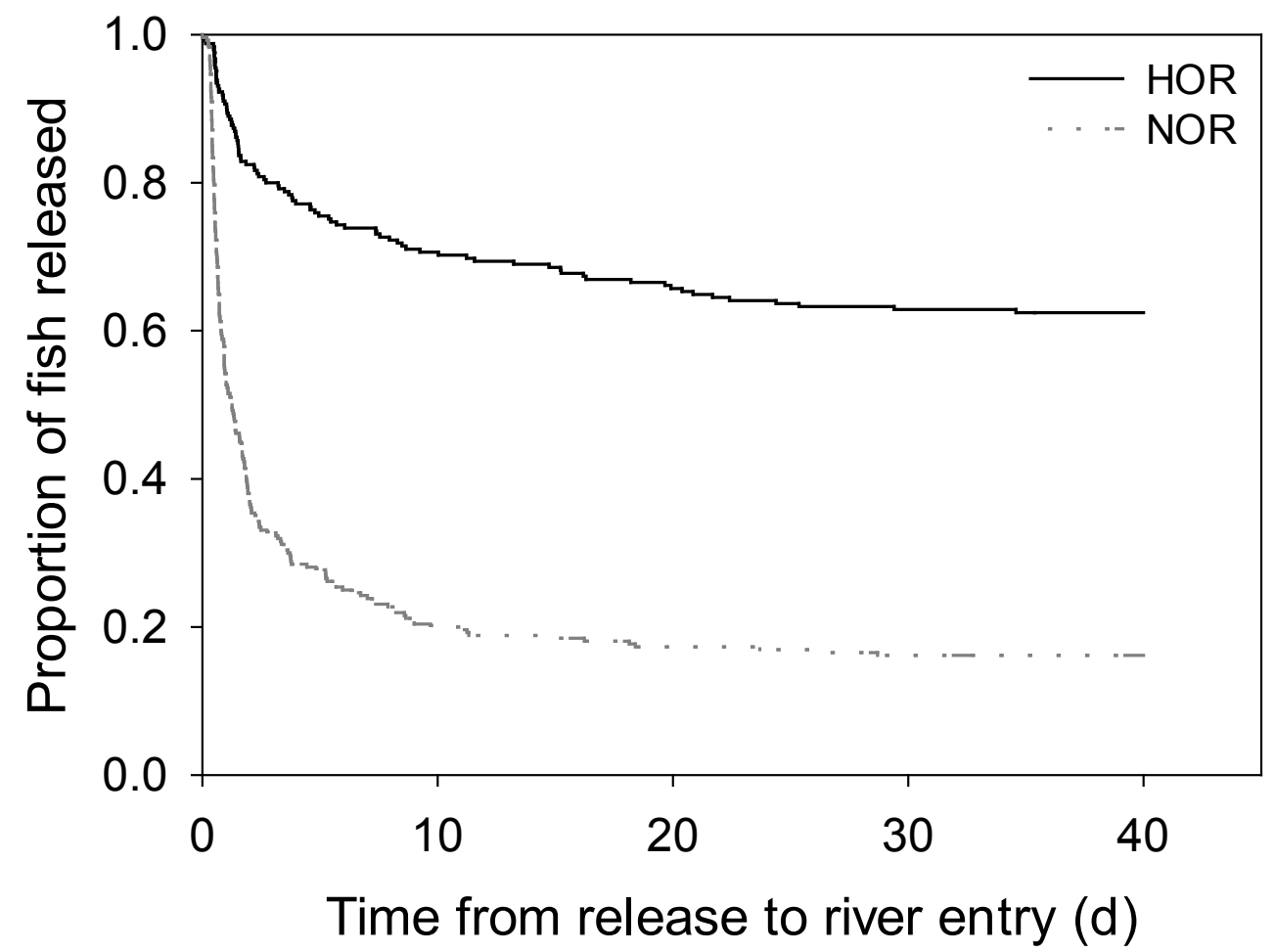

Figure 6. Graph showing survival distribution function of elapsed time from release of radio-tagged adult steelhead in Lake Scanewa to entry in the Cowltiz River or Cispus River, Washington, 2006-09 and 2012. Data include hatchery-origin (HOR) and natural-origin (NOR) fish. 
Table 3. Number of adult steelhead detected in Lake Scanewa, Cowlitz River, or Cispus River following release at one of three locations in the upper Cowlitz River Basin, Washington, 2006-09 and 2012.

[Data include hatchery-origin (HOR) and natural-origin (NOR) fish. Numbers in parentheses are the percentage of fish in each group]

\begin{tabular}{lccccc}
\hline \multicolumn{1}{c}{ Release site } & Origin & Number released & Lake Scanewa & Cowlitz River & Cispus River \\
\hline Reservoir & HOR & 245 & $245(100)$ & $56(23)$ & $44(18)$ \\
\multirow{3}{*}{ Cowlitz River } & NOR & 260 & $260(100)$ & $173(67)$ & $74(28)$ \\
& HOR & 42 & $7(17)$ & $42(100)$ & $5(12)$ \\
Cispus River & NOR & 21 & $13(62)$ & $21(100)$ & $2(10)$ \\
& HOR & 54 & $11(20)$ & $1(2)$ & $54(100)$ \\
& NOR & 25 & $12(48)$ & $5(20)$ & $25(100)$ \\
\hline
\end{tabular}

Table 4. Number of adult steelhead detected in upstream and downstream reaches of the Cowlitz River and Cispus River following release in Lake Scanewa, Washington, 2006-09 and 2012.

[Data include hatchery-origin (HOR) and natural-origin (NOR) fish. Numbers in parentheses are the percentage of fish in each group]

\begin{tabular}{l|c|cccc}
\hline & Number of fish & \multicolumn{2}{|c|}{ Cowlitz River } & \multicolumn{2}{c}{ Cispus River } \\
\cline { 3 - 6 } Origin & released & Downstream reach & Upstream reach & Downstream reach & Upstream reach \\
\hline HOR & 245 & $56(23)$ & $19(8)$ & $43(18)$ & $16(7)$ \\
NOR & 260 & $173(67)$ & $79(30)$ & $74(28)$ & $40(15)$ \\
\hline
\end{tabular}

Table 5. Median elapsed time from release of radio-tagged adult steelhead to first detection in the Cowlitz River, Cispus River, or Lake Scanewa, Washington, 2006-09 and 2012.

[Data include hatchery-origin (HOR) and natural-origin (NOR) fish. Elapsed times were calculated by subtracting the date and time of first detection in one of the rivers from the date and time of release in Lake Scanewa

\begin{tabular}{l|ccc}
\hline \multirow{2}{*}{ Origin } & \multicolumn{3}{c}{ Median elapsed time, in days, by month of release } \\
\cline { 2 - 4 } & March & April & May \\
\hline HOR & 10.0 & 2.7 & 1.5 \\
NOR & 1.9 & 1.0 & 0.7 \\
\hline
\end{tabular}


A substantial number of river-released NOR steelhead moved downstream and entered Lake Scanewa but most HOR steelhead remained in one of the rivers following release (table 3). Sixty-two percent of the NOR steelhead that were released in the Cowlitz River and 48 percent of the NOR fish that were released in the Cispus River moved downstream following release and were detected in Lake Scanewa. In contrast, only 17 percent of the HOR steelhead that were released in the Cowlitz River and 20 percent of the fish that were released in the Cispus River moved downstream to the reservoir (table $3)$. Most radio-tagged steelhead (99-100 percent) made two or fewer trips between the reservoir and one of the rivers prior to spawning (table 6).

Table 6. Number of trips made by adult steelhead between Lake Scanewa and the Cowlitz River or Cispus River, Washington, 2006-09 and 2012.

[Data include hatchery-origin (HOR) and natural-origin (NOR) fish. Numbers in parentheses are the percentage of tagged fish from each group]

\begin{tabular}{c|cc|ccc}
\hline \multirow{2}{*}{ Number of trips } & \multicolumn{2}{|c|}{ Lake Scanewa release } & \multicolumn{2}{c}{ Cowlitz River release } & Cispus River release \\
\cline { 2 - 5 } & HOR & NOR & HOR & NOR & NOR \\
\hline 0 & $163(67)$ & $62(24)$ & $37(88)$ & $9(43)$ & $14(56)$ \\
1 & $69(28)$ & $168(65)$ & $4(10)$ & $12(57)$ & $10(40)$ \\
2 & $10(4)$ & $25(10)$ & $1(2)$ & 0 & $1(4)$ \\
3 & $1(<1)$ & $4(2)$ & 0 & 0 & 0 \\
4 & $1(<1)$ & $1(<1)$ & 0 & 0 & 0 \\
5 & 0 & 0 & 0 & 0 & 0 \\
6 & $1(<1)$ & 0 & 0 & 0 & 0 \\
\hline
\end{tabular}

\section{Fates}

Most NOR steelhead that were released into Lake Scanewa had Cowlitz River or Cispus River fates, whereas HOR steelhead primarily remained in the reservoir or fell back downstream of Cowlitz Falls Dam. We found that 82 percent of the reservoir-released NOR steelhead had Cowlitz River or Cispus River fates (tables 7 and 8). In contrast, nearly two-thirds (65 percent) of the HOR steelhead that were released into Lake Scanewa had a reservoir or fallback fate (table 7). In total, 22.0 percent of the reservoir-released HOR steelhead and 6.9 percent of the reservoir-released NOR steelhead fell back downstream of Cowlitz Falls Dam before spawning occurred (table 7). This difference was statistically significant $\left(\chi^{2}=23.6, P<0.0001\right)$. Substantial annual variability in fallback rates were observed-HOR steelhead fallback ranged from 4.3 to 31.8 percent and NOR fallback ranged from 0.0 to 23.3 percent. Fallback was highest for both HOR and NOR steelhead in 2012 (table 7). We visually assessed the relationship between average monthly discharge and percentage of fallback for monthly release groups of tagged steelhead that were released into Lake Scanewa. This assessment showed that fallback generally was higher for groups of fish when monthly discharge was $6,000 \mathrm{ft}^{3} / \mathrm{s}$ or greater (fig. 7). 
Table 7. Number of radio-tagged adult steelhead assigned to Cowlitz River, Cispus River, Lake Scanewa, and fallback fates, Washington, 2005-09 and 2012.

[Data include hatchery-origin (HOR) and natural-origin (NOR) fish]

\begin{tabular}{lllcccr}
\hline \multicolumn{1}{c}{ Release site } & Origin & Year & Cowlitz River & Cispus River & $\begin{array}{c}\text { Lake } \\
\text { Scanewa }\end{array}$ & Fallback \\
\hline Lake Scanewa & HOR & 2006 & 28.3 & 23.9 & 43.5 & 4.3 \\
& & 2007 & 23.5 & 29.4 & 23.5 & 23.5 \\
& & 2008 & 39.4 & 27.3 & 27.3 & 6.1 \\
& & 2009 & 7.3 & 7.6 & 52.3 & 31.8 \\
& & Overall & 18.4 & 16.3 & 43.3 & 22.0 \\
\hline Lake Scanewa & NOR & 2006 & 62.8 & 25.5 & 7.4 & 4.3 \\
& & 2007 & 37.1 & 37.1 & 20.0 & 5.7 \\
& & 2008 & 50.7 & 38.4 & 11.0 & 0.0 \\
& & 2009 & 40.0 & 13.3 & 33.3 & 13.3 \\
& & 2012 & 53.5 & 18.6 & 4.7 & 23.3 \\
\hline Cowlitz River & HOR & 2008 & 93.1 & 28.8 & 11.2 & 6.9 \\
\hline Cowlitz River & NOR & 2012 & 66.7 & 7.1 & 0 & 0 \\
\hline Cispus River & HOR & 2006 & 0 & 9.5 & 9.5 & 14.3 \\
& & 2008 & 0 & 94.7 & 12.5 & 0 \\
& & Overall & 0 & 92.6 & 2.6 & 2.6 \\
\hline Cispus River & NOR & 2012 & 20.0 & 72.0 & 8.6 & 1.9 \\
\hline
\end{tabular}

Table 8. Percentage of adult steelhead, Chinook salmon, and coho salmon that fell back downstream of Cowlitz Falls Dam prior to spawning, Washington, 2005-09 and 2012.

[Data from the Cowlitz River and Cispus River release sites were pooled to obtain data shown in the river release sites column. Numbers in parentheses are the number of fish in each group]

\begin{tabular}{lcccc}
\hline \multirow{2}{*}{ Species } & \multicolumn{2}{c|}{ Reservoir release site } & \multicolumn{2}{c}{ River release sites } \\
\cline { 2 - 5 } & Did not fallback & Did fallback & Did not fallback & Did fallback \\
\hline \multicolumn{5}{c}{ Hatchery origin } \\
\hline Steelhead & $78(191)$ & $22(54)$ & $99(95)$ & $1(1)$ \\
Chinook salmon & $78(312)$ & $22(88)$ & $86(174)$ & $14(29)$ \\
Coho salmon & $83(105)$ & $17(22)$ & $95(161)$ & $5(8)$ \\
\hline \multicolumn{5}{r}{ Natural origin } \\
\hline Steelhead & $93(242)$ & $7(18)$ & $89(41)$ & $11(5)$ \\
Chinook salmon & $85(123)$ & $15(22)$ & $68(15)$ & $32(7)$ \\
Coho salmon & $93(108)$ & $7(8)$ & $100(49)$ & $0(0)$ \\
\hline \multicolumn{5}{c}{ Hatchery origin and natural origin } \\
\hline Steelhead & & $14(72)$ & $96(136)$ & $4(6)$ \\
Chinook salmon & $86(433)$ & $20(110)$ & $84(189)$ & $16(36)$ \\
Coho salmon & $80(435)$ & $12(30)$ & $96(210)$ & $4(8)$ \\
\hline
\end{tabular}




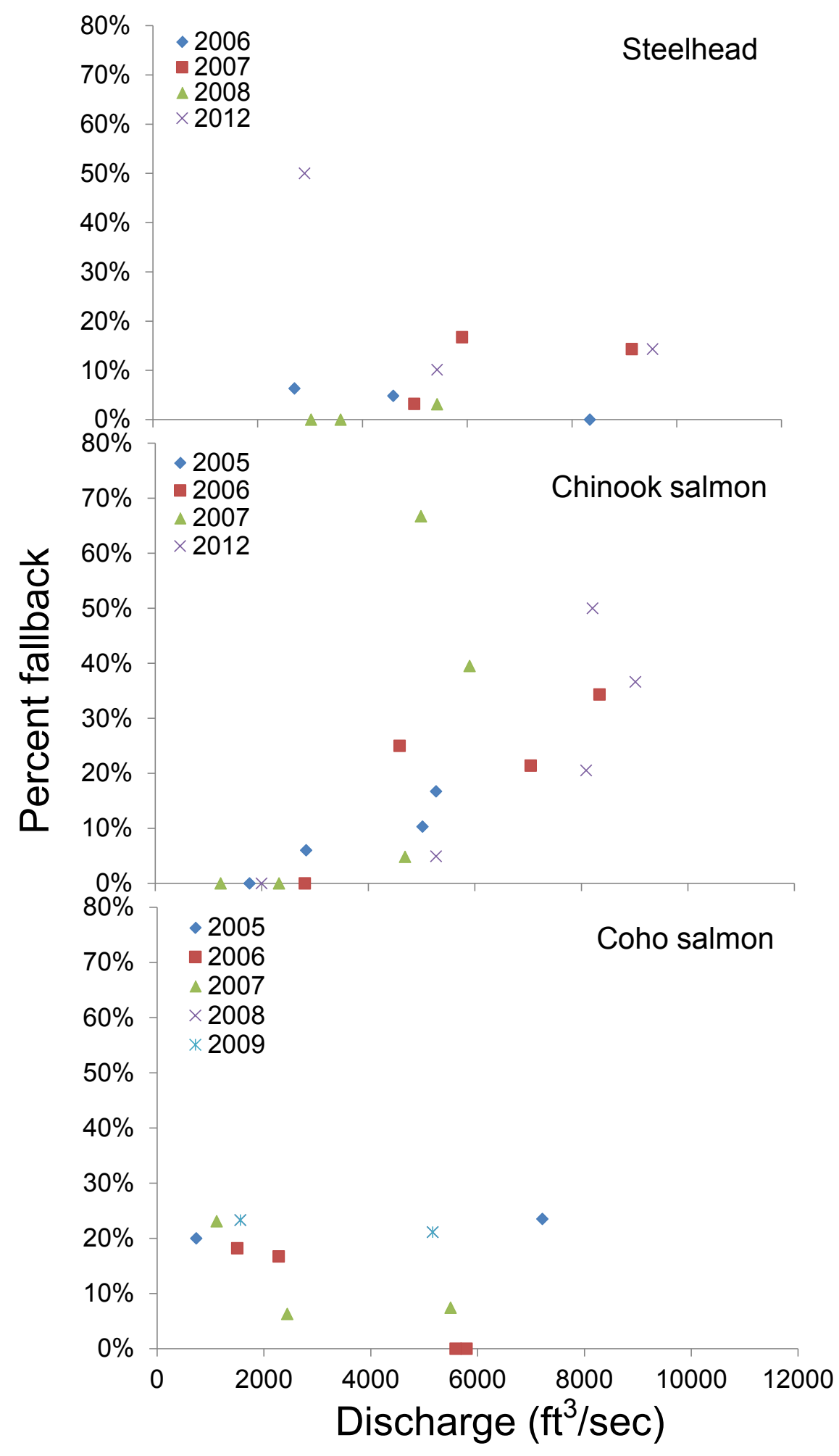

Figure 7. Graphs showing relationship between monthly average discharge and percentage of fallback for monthly release groups of steelhead, Chinook salmon, and coho salmon, upper Cowlitz River Basin, Washington, 2005-09 and 2012. 
Most radio-tagged steelhead that were released into the Cowlitz or Cispus Rivers remained in the tributary where they were released (table 7), regardless of origin. We found that 92.9 percent of the HOR steelhead and 66.7 percent of the NOR steelhead that were released into the Cowlitz River had Cowlitz River fates (table 7). Similarly, 92.6 percent of the HOR steelhead and 72.0 percent of the NOR steelhead that were released into the Cispus River had Cispus River fates (table 7). In total, 96 HOR steelhead were released into the Cowlitz or Cispus Rivers during the study period, and only 1 of those fish (1 percent) fell back downstream of Cowlitz Falls Dam. This fallback rate was significantly lower than the fallback rate for HOR steelhead that were released into Lake Scanewa $\left(\chi^{2}=22.4, P<0.0001\right.$; table 7). In contrast, 46 NOR steelhead were released at the river release sites and 3 ( 7 percent) of those fish fell back, which was not significantly different from NOR steelhead that were released into Lake Scanewa $\left(\chi^{2}=0.01, P=0.921\right.$; table 7$)$.

Kelts

We found that 11.7 percent of the radio-tagged steelhead fell back downstream of Cowlitz Falls Dam prior to spawning, and 33.5 percent of the fish that remained upstream of the dam did not move downstream as kelts (table 9). About one-fourth (25.7 percent) of the tagged steelhead moved downstream and were last detected in Lake Scanewa as kelts, and 16.5 percent were collected at the Cowlitz Falls Fish Facility (table 8). The remaining steelhead (12.5 percent) passed downstream of Cowlitz Falls Dam. There was no difference in the percentage of HOR fish (63.6 percent) and NOR fish (60.4 percent; $\left.\chi^{2}=0.64, P=0.419\right)$ that moved downstream after spawning. However, a higher percentage of female fish (68.3 percent) moved downstream than male fish ( 55.9 percent; $\chi^{2}=9.41, P=$ 0.002). We determined the percentage of kelts that were collected at the Cowlitz Falls Fish Facility by dividing the number of kelts collected by the total number of kelts that remained in Lake Scanewa, were collected, or passed the dam after spawning. In total, 30.2 percent of the steelhead kelts were collected during our study period. The breakdown by sex and origin of kelts that were collected included the following - 22.9 percent of male HOR steelhead; 33.7 percent of female HOR steelhead; 30.3 percent of male NOR steelhead; and 34.0 percent of female NOR steelhead.

Table 9. Percentage of adult steelhead kelts that remained upstream of Cowlitz Falls Dam, that were collected at the dam, or that passed downstream of the dam, Washington, 2005-09 and 2012.

\begin{tabular}{llccccc}
\hline \multirow{2}{*}{ Origin } & Sex & $\begin{array}{c}\text { Pallback prior } \\
\text { to spawning }\end{array}$ & $\begin{array}{c}\text { Not detected moving } \\
\text { downstream }\end{array}$ & $\begin{array}{c}\text { Last detected in } \\
\text { Lake Scanewa }\end{array}$ & $\begin{array}{c}\text { Collected at Cowlitz } \\
\text { Falls Dam }\end{array}$ & $\begin{array}{c}\text { Fallback after } \\
\text { spawning }\end{array}$ \\
\hline HOR & Male & 16.6 & 35.2 & 31.7 & 11.1 & 5.5 \\
& Female & 15.5 & 23.9 & 27.5 & 20.4 & 12.7 \\
NOR & Male & 8.1 & 43.0 & 22.2 & 14.8 & 11.9 \\
& Female & 5.8 & 32.2 & 19.9 & 21.1 & 21.1 \\
\hline Total & & 11.7 & 33.5 & 25.7 & 16.5 & 12.5 \\
\hline
\end{tabular}




\section{Chinook Salmon}

\section{Tagging and Release}

A total of 842 Chinook salmon were radio-tagged, but 72 fish ( 8.5 percent) regurgitated their transmitter prior to, or shortly after, release (table 10). As a result, the final tagged population was comprised of 770 fish that were nearly evenly split between females (396 fish; 51 percent) and males (374 fish; 49 percent). Most tagged fish were of hatchery-origin (581 fish; 78 percent; table 9). The average size of female Chinook salmon $(77.6 \mathrm{~cm})$ was larger $(t=3.52, P=0.0005)$ than male Chinook salmon $(75.8 \mathrm{~cm})$, but there was no size difference between NOR and HOR fish $(76.6$ and $76.9 \mathrm{~cm}$, respectively; $t=-0.43, P=0.665)$. Seventy-one percent of the tagged Chinook salmon were released into Lake Scanewa, 20 percent were released into the Cowlitz River, and 9 percent were released into the Cispus River (table 10). Chinook salmon were released during April-August (fig. 8).

Table 10. Number of adult Chinook salmon radio-tagged, released, and monitored in the upper Cowlitz River Basin, Washington, 2005-07 and 2012.

[Data include hatchery-origin (HOR) and natural-origin fish (NOR). Numbers in parentheses are tagged fish that regurgitated their transmitter during transport or at the release site]

\begin{tabular}{c|cc|cc|cr}
\hline \multirow{2}{*}{ Year } & \multicolumn{2}{c|}{ Lake Scanewa release site } & \multicolumn{2}{c}{ Cowlitz River release site } & \multicolumn{2}{c}{ Cispus River release site } \\
\cline { 2 - 6 } & HOR & NOR & HOR & NOR & HOR \\
\hline 2005 & $136(16)$ & $42(7)$ & 21 & 0 & 21 & 0 \\
2006 & $105(15)$ & $33(13)$ & 0 & 0 & 0 \\
2007 & $51(7)$ & $42(5)$ & $50(2)$ & 0 & $52(3)$ & 0 \\
2012 & $108(3)$ & 28 & $59(1)$ & 22 & 0 \\
\hline Total & 400 & 145 & 130 & 22 & 0 \\
\hline
\end{tabular}




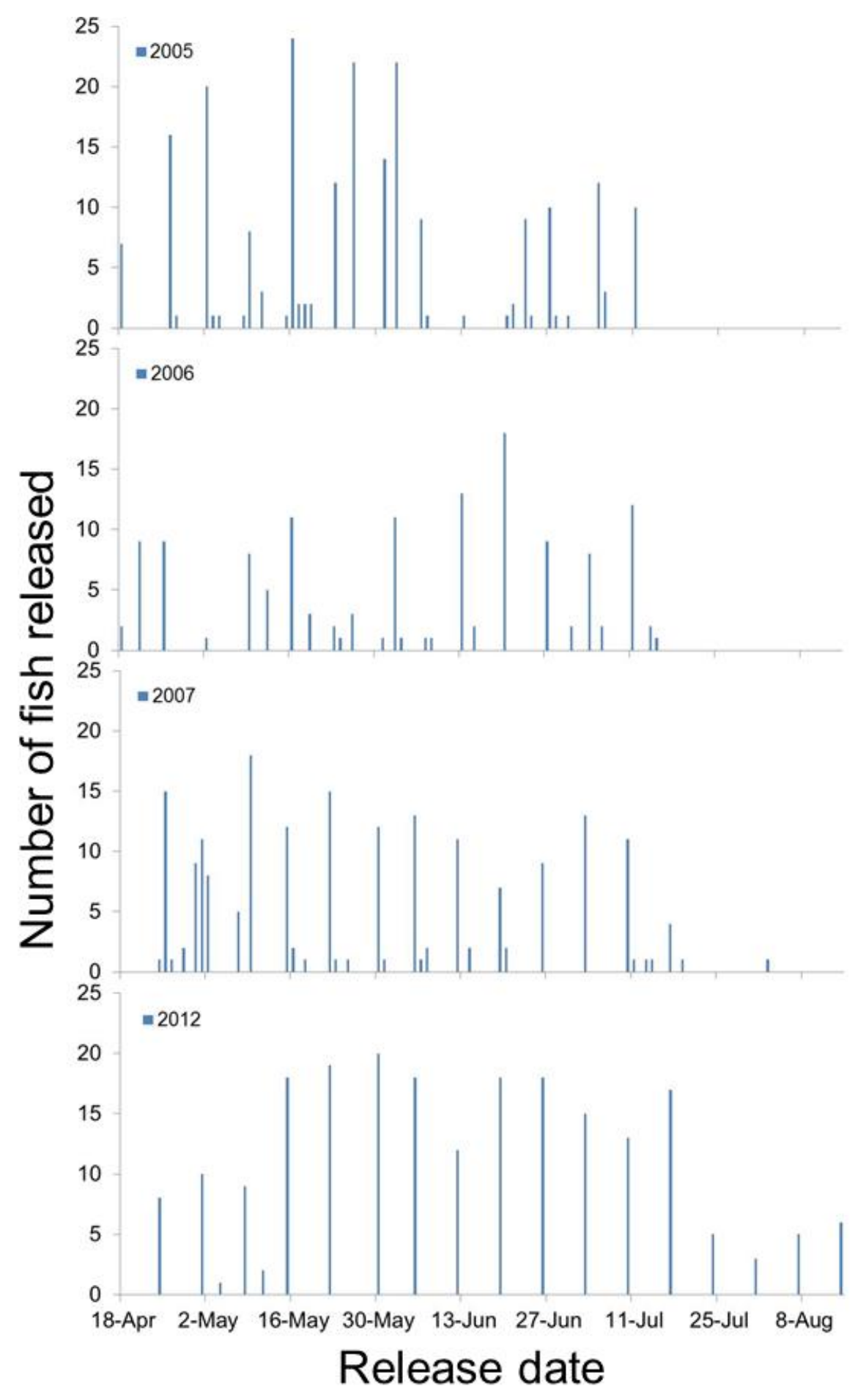

Figure 8. Graphs showing number of adult Chinook salmon radio-tagged and released in the upper Cowlitz River Basin, Washington, 2005-07 and 2012. 


\section{Behavior}

We found distinct differences between HOR and NOR Chinook salmon responses to release in Lake Scanewa. In total, 67 percent of the reservoir-released HOR Chinook salmon and 84 percent of the NOR Chinook salmon moved upstream and were detected in the Cowlitz River or Cispus River. Median elapsed time from reservoir release to river entry was $21.0 \mathrm{~d}$ for HOR Chinook salmon and $6.6 \mathrm{~d}$ for NOR Chinook salmon. These data showed that NOR Chinook salmon were more likely than HOR Chinook salmon to move upstream and enter one of the rivers, and the NOR fish initiated upstream movement quicker than the HOR fish (Wilcoxon text $\chi^{2}=35.1, P<0.0001$; fig. 9). Tagged Chinook salmon were more likely to enter the Cowlitz River than the Cispus River, and this relationship did not vary by origin (table 11). Seventy percent of the NOR Chinook salmon and 47 percent of the HOR Chinook salmon that were released into Lake Scanewa moved upstream and entered the Cowlitz River (table 11). More than one-half of the NOR Chinook salmon (52 percent) and about one-fourth of the HOR Chinook salmon (23 percent) entered the upstream reach of the Cowlitz River (table 12). In contrast, 26 percent of the NOR Chinook salmon and 38 percent of the HOR Chinook salmon entered the Cispus River and the percentage of tagged fish that entered the upstream reach of the river was 18 and 21 percent, respectively (table 12). Median residence times generally were higher for fish released early in the year (April and May) than for fish released in June, July, or August (table 12). Naturalorigin Chinook salmon spent less time in the reservoir before moving upstream than HOR Chinook salmon in all release months (table 13). Many of the reservoir-released fish made multiple trips between the reservoir and the Cowlitz River or Cispus River during the pre-spawning period, regardless of origin (table 14). Reservoir-released fish entered the Cowlitz River for spawning earlier than fish that entered the Cispus River (fig. 10). Seventy-two percent of the fish that had Cowlitz River fates moved upstream of the reservoir during July and August whereas 89 percent of the fish with Cispus River fates entered the river during August and September.

More than one-half of the Cowlitz-released Chinook salmon (HOR $=57$ percent; $\mathrm{NOR}=59$ percent) moved downstream and entered Lake Scanewa and few of these fish entered the Cispus River (14 percent or less; table 11). Forty percent of the HOR Chinook salmon that were released at the Cispus River release site were detected in Lake Scanewa and 16 percent of the fish were detected in the Cowlitz River. There were no strong trends in river residence times between release month, release location, or fish origin (table 13). Many of the river-released fish made multiple trips between the Cowlitz River or Cispus River and the reservoir during the pre-spawning period (table 14).

Table 11. Number of adult Chinook salmon detected in Lake Scanewa, Cowlitz River, or the Cispus River following release at one of three locations in the upper Cowlitz River Basin, Washington, 2005-07 and 2012.

[Data include hatchery-origin (HOR) and natural-origin (NOR) fish. Numbers in parentheses are the percentage of fish from each release group]

\begin{tabular}{llcccc}
\hline \multicolumn{1}{c}{ Release site } & Origin & Number released & Lake Scanewa & Cowlitz River & Cispus River \\
\hline Reservoir & HOR & 400 & $400(100)$ & $187(47)$ & $153(38)$ \\
& NOR & 145 & $145(100)$ & $102(70)$ & $37(25)$ \\
Cowlitz River & HOR & 130 & $74(57)$ & $130(100)$ & $18(14)$ \\
& NOR & 22 & $13(59)$ & $22(100)$ & 0 \\
Cispus River & HOR & 73 & $29(40)$ & $12(16)$ & $73(100)$ \\
\hline
\end{tabular}


Table 12. Number of Chinook salmon that were detected in upstream and downstream reaches of the Cowlitz River or Cispus River following release in Lake Scanewa, Washington, 2005-07 and 2012.

[Data include hatchery-origin (HOR) and natural-origin (NOR) fish. Numbers in parentheses are the percentage of fish from each release group]

\begin{tabular}{l|c|cc|cr}
\hline & Number of & \multicolumn{2}{|c|}{ Cowlitz River } & \multicolumn{2}{c}{ Cispus River } \\
\cline { 3 - 6 } Origin & fish released & Downstream reach & Upstream reach & Downstream reach & Upstream reach \\
\hline HOR & 400 & $187(47)$ & $92(23)$ & $153(38)$ & $83(21)$ \\
NOR & 145 & $102(70)$ & $76(52)$ & $37(26)$ & $26(18)$ \\
\hline
\end{tabular}

Table 13. Median elapsed time from release of radio-tagged Chinook salmon to first detection in the Cowlitz River, Cispus River, or Lake Scanewa, Washington, 2005-07 and 2012.

[Data include hatchery-origin (HOR) and natural-origin (NOR) fish. Elapsed times were calculated from the time of release to first detection in the Cowlitz River or Cispus River for fish that were released at the reservoir release site, or first detection in the reservoir for fish that were released at the Cowlitz River or Cispus River release sites]

\begin{tabular}{lcccccc}
\hline & & \multicolumn{5}{c}{ Median elapsed time, in days, by month of release } \\
\cline { 3 - 7 } Release site & Origin & April & May & June & July & August \\
\hline Reservoir & HOR & 43.3 & 16.9 & 26.3 & 9.3 & 7.2 \\
\multirow{2}{*}{ Cowlitz River } & NOR & 11.9 & 8.6 & 6.1 & 3.3 &. \\
& HOR & 22.3 & 24.1 & 17.7 & 8.4 &. \\
Cispus River & NOR & 39.7 &. &. &. &. \\
\hline
\end{tabular}

Table 14. Number of trips made by Chinook salmon between Lake Scanewa and the Cowlitz River or Cispus River, Washington, 2005-07 and 2012.

[Data include hatchery-origin (HOR) and natural-origin (NOR) fish. Numbers in parentheses are the percentage of tagged fish from each group]

\begin{tabular}{c|cc|ccc}
\hline \multirow{2}{*}{ Number of trips } & \multicolumn{2}{|c|}{ Lake Scanewa release } & \multicolumn{2}{c|}{ Cowlitz River release } & Cispus River release \\
\cline { 2 - 5 } & HOR & NOR & HOR & NOR & NOR \\
\hline 0 & $136(34)$ & $37(26)$ & $64(49)$ & $12(55)$ & $48(66)$ \\
1 & $152(38)$ & $75(52)$ & $33(25)$ & $6(27)$ & $15(21)$ \\
2 & $59(15)$ & $22(15)$ & $13(10)$ & $3(14)$ & $4(5)$ \\
3 & $28(7)$ & $6(4)$ & $9(7)$ & $1(5)$ & $1(1)$ \\
4 & $16(4)$ & $4(3)$ & $7(5)$ & 0 & $3(4)$ \\
5 & $5(1)$ & $1(<1)$ & $1(<1)$ & 0 & $1(1)$ \\
6 & $1(<1)$ & 0 & 0 & 0 & 0 \\
7 & $1(<1)$ & 0 & $1(<1)$ & 0 & $1(1)$ \\
8 & $2(<1)$ & 0 & $2(1)$ & 0 & 0 \\
\hline
\end{tabular}




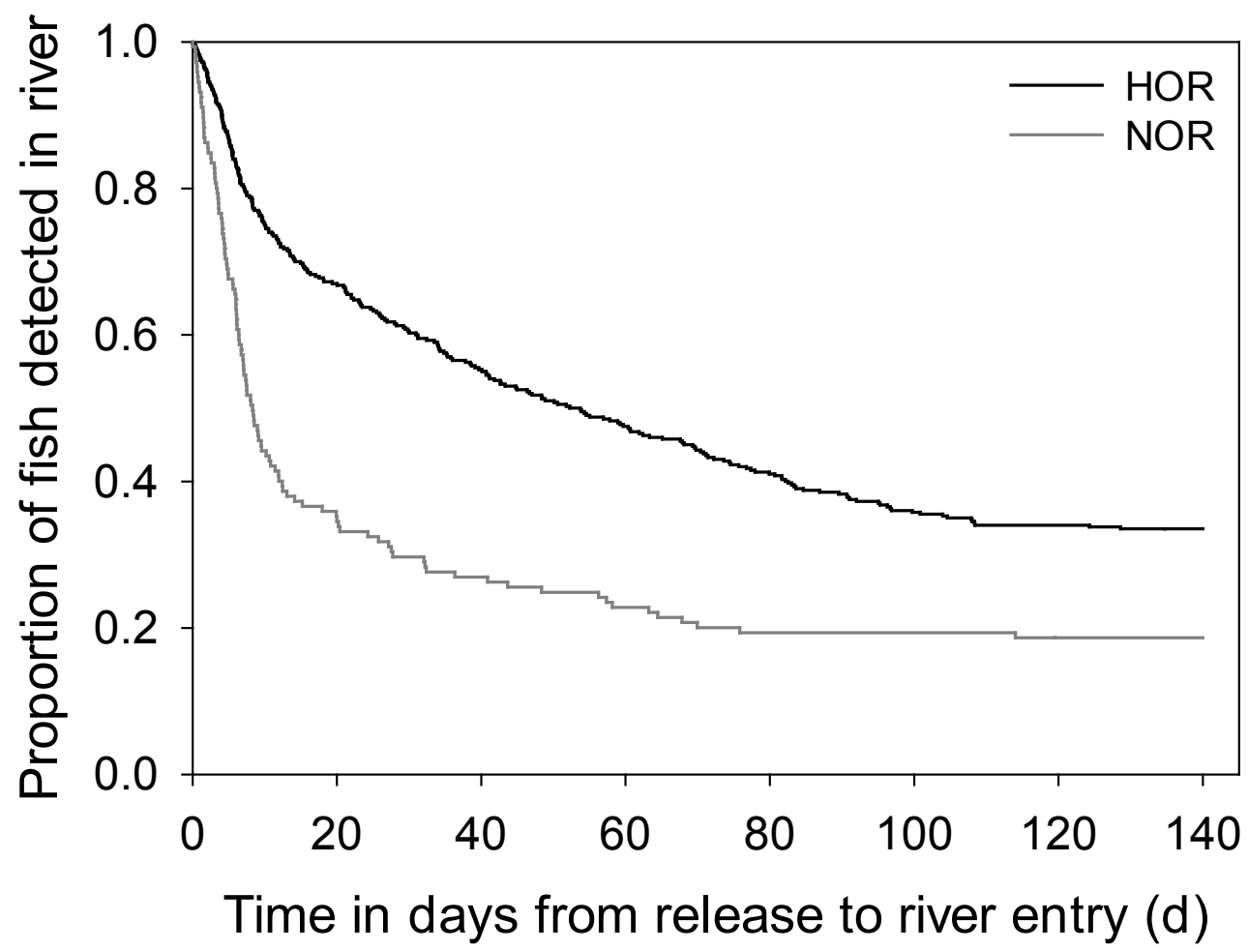

Figure 9. Graph showing survival distribution function of elapsed time from release of radio-tagged adult Chinook salmon in Lake Scanewa to entry in the Cowltiz River or Cispus River, Washington, 2005-07 and 2012. Data include hatchery-origin (HOR) and natural-origin (NOR) fish.

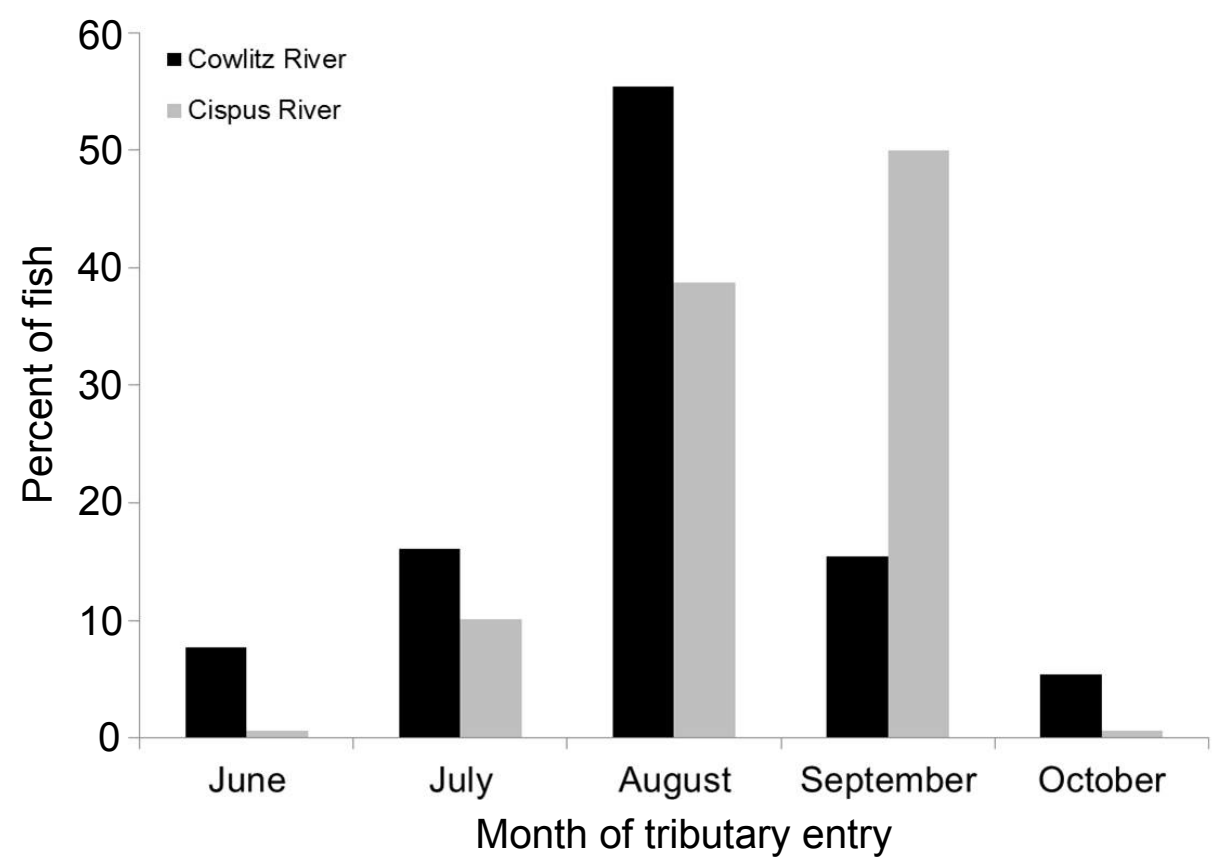

Figure 10. Graph showing percentage of radio-tagged Chinook salmon that entered the Cowlitz or Cispus Rivers after being released into Lake Scanewa, Washington, June-October, 2005-07 and 2012. 


\section{Fates}

Reservoir-released Chinook salmon did not have a predominant fate and substantial variability was observed between fish of different origins and during different study years. The largest percentage of reservoir-released HOR Chinook salmon (30.8 percent) had Cispus River fates and the smallest percentage (18.8 percent; table 15) had Cowlitz River fates. Approximately one-third of the HOR Chinook salmon had Cispus River fates during each year of the evaluation, but the percentage of fish with Cowlitz River fates ranged from 9.8 percent in 2007 to 24.3 percent in 2005 . The sum of Cowlitz River and Cispus River fates for reservoir-released HOR Chinook salmon was 49.6 percent (table 15). Fallback rates for HOR Chinook salmon were 22.0 percent overall and ranged from 13.2 percent in 2005 to 45.1 percent in 2007 (tables 8and 15). The largest percentage of reservoir-released NOR Chinook salmon (37.9 percent) had Cowlitz River fates and the smallest percentage (15.2 percent; table 15) had fallback fates. During 2007, more than one-half (57.1 percent; table 15) of the NOR Chinook salmon that were released into the reservoir had Cowlitz River fates, but only 21.4 percent of the fish had this same fate in 2005. A higher percentage of reservoir-released HOR Chinook salmon (22 percent) had fallback fates than NOR Chinook salmon (15 percent; table 15) but this difference was not statistically significant $\left(\chi^{2}=3.08, P=0.08\right)$. We visually assessed the relationship between monthly average discharge and percentage of fallback for monthly release groups of tagged Chinook salmon that were released into Lake Scanewa. This assessment showed that fallback generally was low for groups of fish when monthly discharge was less than $3,000 \mathrm{ft}^{3} / \mathrm{s}$ (fig. 7). However, fallback rates increased with increasing discharge within the discharge range of 4,000 to $9,000 \mathrm{ft}^{3} / \mathrm{s}$ (fig. 7).

Releases of tagged Chinook salmon into the Cowlitz River or Cispus River resulted in higher percentages of fish having fates located upstream of Lake Scanewa. We found that 60.8 percent of the HOR Chinook salmon and 50.0 percent of the NOR Chinook salmon that were released into the Cowlitz River had that fate when the study concluded (table 14). The remaining Cowlitz-released HOR Chinook salmon had fallback (15.4 percent), reservoir (12.3 percent), and Cispus River (11.5 percent) fates. The remaining Cowlitz-released NOR Chinook salmon had fallback (31.8 percent) and Lake Scanewa (18.2 percent; table 15) fates. We only released HOR Chinook salmon into the Cispus River and found that 74.0 percent of those fish had Cispus River fates, while the rest of the fish had Lake Scanewa (12.3 percent), fallback (12.3 percent), and Cowlitz River fates (1.4 percent; table 15). Fallback rates for riverreleased fish (16.0 percent) were lower than for reservoir-released fish ( 20.2 percent) but this difference was not significant $\left(\chi^{2}=1.81, P=0.18\right)$. 
Table 15. Number of radio-tagged adult Chinook salmon assigned to Cowlitz River, Cispus River, Lake Scanewa, and fallback fates, Washington, 2005-07 and 2012.

[Data include hatchery-origin (HOR) and natural-origin (NOR) fish]

\begin{tabular}{|c|c|c|c|c|c|c|}
\hline \multirow[b]{2}{*}{ Release site } & \multirow[b]{2}{*}{ Origin } & \multirow[b]{2}{*}{ Year } & \multicolumn{4}{|c|}{$\begin{array}{r}\text { Fate } \\
\end{array}$} \\
\hline & & & Cowlitz River & Cispus River & Lake Scanewa & Fallback \\
\hline \multirow{5}{*}{ Lake Scanewa } & HOR & 2005 & 24.3 & 28.7 & 33.8 & 13.2 \\
\hline & & 2006 & 21.0 & 30.5 & 24.8 & 23.8 \\
\hline & & 2007 & 9.8 & 33.3 & 11.8 & 45.1 \\
\hline & & 2012 & 13.9 & 32.4 & 33.3 & 20.4 \\
\hline & & Overall & 18.8 & 30.8 & 28.5 & 22.0 \\
\hline \multirow[t]{5}{*}{ Lake Scanewa } & NOR & 2005 & 21.4 & 23.8 & 50.0 & 4.8 \\
\hline & & 2006 & 30.3 & 33.3 & 18.2 & 18.2 \\
\hline & & 2007 & 57.1 & 21.4 & 9.5 & 11.9 \\
\hline & & 2012 & 42.9 & 17.9 & 7.1 & 32.1 \\
\hline & & Overall & 37.9 & 24.1 & 22.8 & 15.2 \\
\hline \multirow[t]{4}{*}{ Cowlitz River } & HOR & 2005 & 76.2 & 0.0 & 23.8 & 0.0 \\
\hline & & 2007 & 62.0 & 16.0 & 4.0 & 18.0 \\
\hline & & 2012 & 54.2 & 11.9 & 15.3 & 18.6 \\
\hline & & Overall & 60.8 & 11.5 & 12.3 & 15.4 \\
\hline Cowlitz River & NOR & 2012 & 50.0 & 0.0 & 18.2 & 31.8 \\
\hline Cispus River & HOR & 2007 & 1.4 & 74.0 & 12.3 & 12.3 \\
\hline
\end{tabular}




\section{Coho Salmon}

\section{Tagging and Release}

A total of 490 coho salmon were tagged during 2005-09. However, 29 fish (5.9 percent) regurgitated their radio transmitter prior to, or shortly after, release (table 16). As a result, the final tagged population of coho salmon included a total of 461 fish. Of those, 306 (66.3 percent) were HOR fish and 184 (39.9 percent) were NOR fish. Hatchery-origin coho salmon averaged $74.1 \mathrm{~cm}$ total length which was significantly larger than NOR coho salmon (average total length $=72.6 \mathrm{~cm}$ total length; $t=$ 2.37, $P=0.02$ ). We tagged 332 female ( 72.0 percent) coho salmon and 129 (28.0 percent) male coho salmon during the study. Male coho salmon $(74.3 \mathrm{~cm}$ average) were slightly larger than female coho salmon $(73.2 \mathrm{~cm}$ average), but these differences were not statistically significant $(t=-1.72, P=0.09)$. About one-half of the tagged fish (54.3 percent) were released into Lake Scanewa and the remaining fish were released in the Cowlitz River (24.7 percent) or Cispus River (13.9 percent; table 16). Tagged fish were released during October-January (fig. 11).

Table 16. Number of adult coho salmon radio-tagged, released, and monitored in the upper Cowlitz River Basin, Washington, 2005-09.

[Data include hatchery-origin (HOR) and natural-origin fish (NOR). Numbers in parentheses are tagged fish that regurgitated their transmitter during transport or at the release site]

\begin{tabular}{c|cc|cccc}
\hline \multirow{2}{*}{ Year } & \multicolumn{2}{|c|}{ Lake Scanewa release site } & \multicolumn{2}{c|}{ Cowlitz River release site } & \multicolumn{2}{c}{ Cispus River release site } \\
\cline { 2 - 6 } & HOR & NOR & HOR & NOR & HOR \\
\hline 2005 & 20 & $39(3)$ & 0 & 0 & 0 & 0 \\
2006 & $28(1)$ & 0 & 26 & 0 & $26(1)$ & 0 \\
2007 & 0 & $68(13)$ & 0 & 0 & $12(3)$ & $22(1)$ \\
2008 & $35(4)$ & $27(2)$ & 36 & 15 & 0 & 0 \\
2009 & 49 & 0 & $44(1)$ & 0 & 68 & 35 \\
\hline Total & 132 & 134 & 106 & 15 & 0 \\
\hline
\end{tabular}




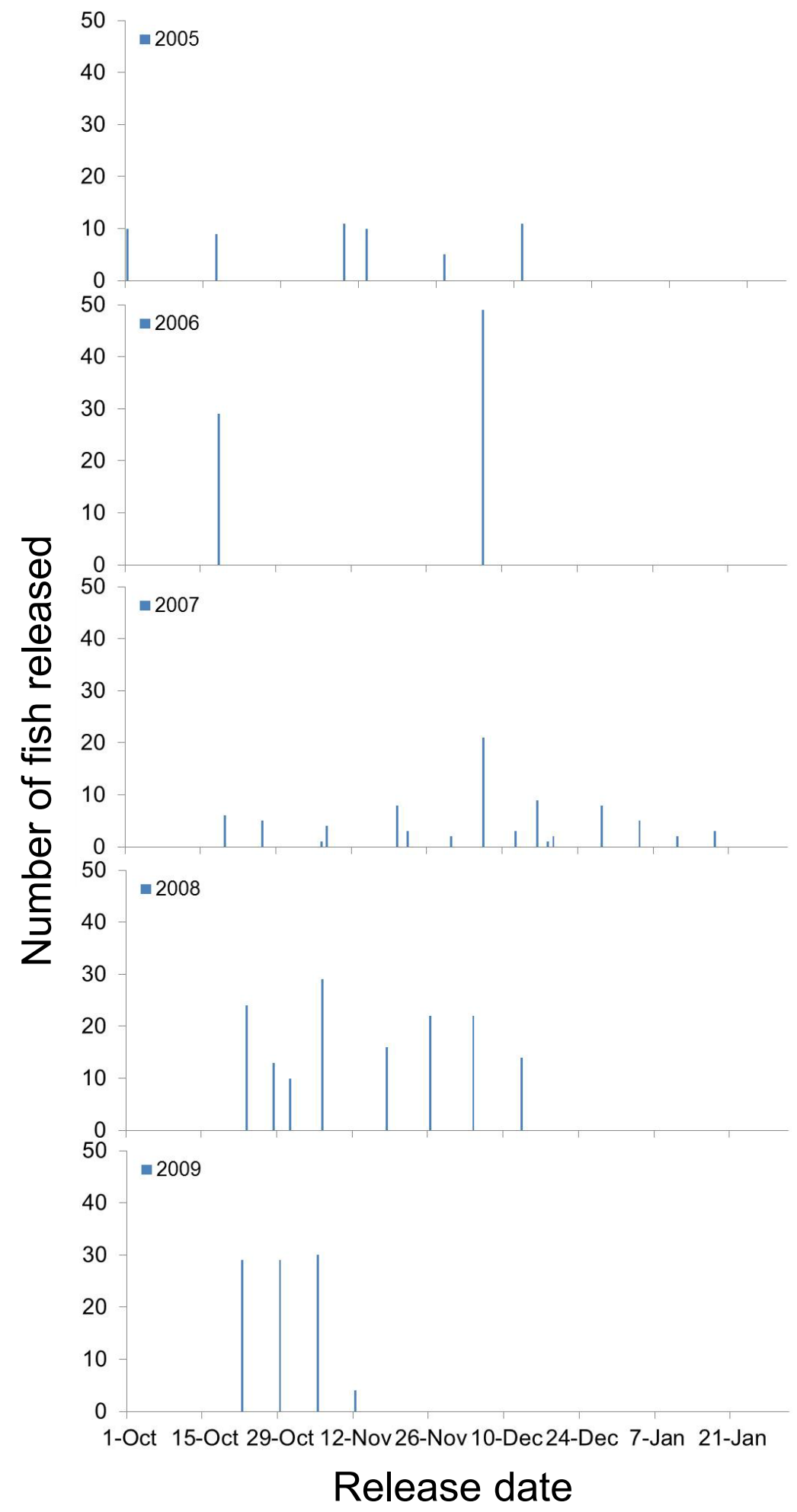

Figure 11. Graphs showing number of adult coho salmon radio-tagged and released in the upper Cowlitz River Basin, Washington, 2005-09. Two fish were tagged and released on August 3, 2007, and are not shown in this figure. 


\section{Behavior}

There were distinct differences in the behavior of HOR and NOR coho salmon following release into Lake Scanewa. We found that 41 percent of the reservoir-released HOR coho salmon moved upstream and were detected in the Cowlitz River or the Cispus River. In contrast, 76 percent of the NOR coho salmon moved upstream into one of the rivers. The HOR coho salmon also took longer to move upstream than the NOR coho salmon. Median time in the reservoir prior to upstream movement was 9.6 $\mathrm{d}$ for HOR fish and $5.4 \mathrm{~d}$ for NOR fish. These differences were statistically significant (Wilcoxon text $\chi^{2}$ $=39.8, P<0.0001$; fig. 12). Both HOR and NOR coho salmon used the Cowlitz River in greater proportions than the Cispus River. Thirty percent of the HOR coho salmon that were released into Lake Scanewa were detected in the Cowlitz River compared to 12 percent in the Cispus River (table 17). Seventy percent of the reservoir-released NOR coho salmon were detected in the Cowlitz River and 10 percent were detected in the Cispus River. Very few of the reservoir-released coho salmon entered the upstream reach of the Cispus River (HOR fish $=3$ percent; NOR fish $=7$ percent; table 18). Seventeen percent of the HOR coho salmon that were released into Lake Scanewa were detected in the upstream reach of the Cowlitz River compared to 41 percent of the NOR coho salmon. Median elapsed time from reservoir release to river entry generally decreased with increasing release month (table 19) and most coho salmon made one or less trips between the reservoir and one of the rivers (table 20).

Few of the radio-tagged coho salmon released into the Cowlitz River or the Cispus River moved downstream and entered Lake Scanewa. Only 15 percent of the HOR coho salmon that were released into the Cowlitz River moved downstream into Lake Scanewa (table 17). All Cowlitz-released NOR coho salmon remained in the Cowlitz River. A small number (two HOR coho salmon; six NOR coho salmon) of the Cispus-released coho salmon moved downstream and entered Lake Scanewa. Both of the HOR coho salmon, and three of the NOR coho salmon then moved upstream and were detected in the Cowlitz River (table 17). Most (94-100 percent) of the tagged coho salmon made one or less trips between the reservoir and the Cowlitz River or the Cispus River (table 20).

Table 17. Number of adult coho salmon detected in Lake Scanewa, Cowlitz River, or Cispus River following release at one of three locations in the upper Cowlitz River Basin, Washington, 2005-09.

[Data include hatchery-origin (HOR) and natural-origin (NOR) fish. Numbers in parentheses are the percentage of fish from each release group]

\begin{tabular}{lccccc}
\hline \multicolumn{1}{c}{ Release site } & Origin & Number released & Lake Scanewa & Cowlitz River & Cispus River \\
\hline Reservoir & HOR & 127 & $127(100)$ & $38(30)$ & $15(12)$ \\
& NOR & 116 & $116(100)$ & $81(70)$ & $12(10)$ \\
Cowlitz River & HOR & 105 & $16(15)$ & $105(100)$ & 0 \\
\multirow{3}{*}{ Cispus River } & NOR & 15 & 0 & $15(100)$ & 0 \\
& HOR & 64 & $1(2)$ & $1(2)$ & $64(100)$ \\
& NOR & 34 & $2(6)$ & $1(3)$ & $34(100)$ \\
\hline
\end{tabular}


Table 18. Number of coho salmon detected in upstream and downstream reaches of the Cowlitz River or Cispus River following release in Lake Scanewa, Washington, 2005-09.

[Data include hatchery-origin (HOR) and natural-origin (NOR) fish. Numbers in parentheses are the percentage of fish from each release group]

\begin{tabular}{ccc|cccc}
\hline \multirow{2}{*}{ Origin } & \multirow{2}{*}{ Number of } & \multicolumn{2}{|c|}{ Cowlitz River } & \multicolumn{2}{c}{ Cispus River } \\
\cline { 3 - 6 } & fish released & Downstream reach & Upstream reach & Downstream reach & Upstream reach \\
\hline HOR & 127 & $38(30)$ & $22(17)$ & $15(12)$ & $4(3)$ \\
NOR & 145 & $81(70)$ & $47(41)$ & $12(10)$ & $8(7)$ \\
\hline
\end{tabular}

Table 19. Median elapsed time from release to first detection of radio-tagged coho salmon in the Cowlitz River, Cispus River, or Lake Scanewa, Washington, 2005-09.

[Data include hatchery-origin (HOR) and natural-origin (NOR) fish. Elapsed times were calculated from the time of release to first detection in the Cowlitz River or Cispus River for fish that were released at the reservoir release site, or from first detection in the reservoir for fish that were released at the Cowlitz River or Cispus River release sites]

\begin{tabular}{lllcll}
\hline \multirow{2}{*}{ Release site } & \multirow{2}{*}{ Origin } & \multicolumn{4}{c}{ Median elapsed time, in days, by month of release } \\
\cline { 3 - 6 } & & October & November & December & January \\
\hline Reservoir & HOR & 18.6 & 6.5 & 6.5 & 0 \\
& NOR & 9.6 & 6.1 & 4.4 & 1.4 \\
Cowlitz River & HOR & 0 & 20.3 & 2.8 & 0 \\
Cispus River & HOR & 8.4 & 0 & 0 & 0 \\
& NOR & 0 & 11.4 & 29.2 & 0 \\
\hline
\end{tabular}

Table 20. Number of trips made by coho salmon between Lake Scanewa and the Cowlitz River or Cispus River, Washington, 2005-09.

Data include hatchery-origin (HOR) and natural-origin (NOR) fish. Numbers in parentheses are the percentage of tagged fish from each group]

\begin{tabular}{c|cccc|cc}
\hline \multirow{2}{*}{ Number of trips } & \multicolumn{2}{|c|}{ Lake Scanewa release } & \multicolumn{2}{c}{ Cowlitz River release } & \multicolumn{2}{c}{ Cispus River release } \\
\cline { 2 - 6 } & HOR & NOR & HOR & NOR & HOR \\
\hline 0 & $91(72)$ & $70(60)$ & $94(90)$ & $15(100)$ & $63(98)$ & $1(2)$ \\
1 & $35(28)$ & $39(34)$ & $7(7)$ & 0 & 0 & $2(94)$ \\
2 & 0 & $7(6)$ & $4(3)$ & 0 & 0 & 0 \\
3 & $1(1)$ & 0 & 0 & 0 & 0 \\
\hline
\end{tabular}




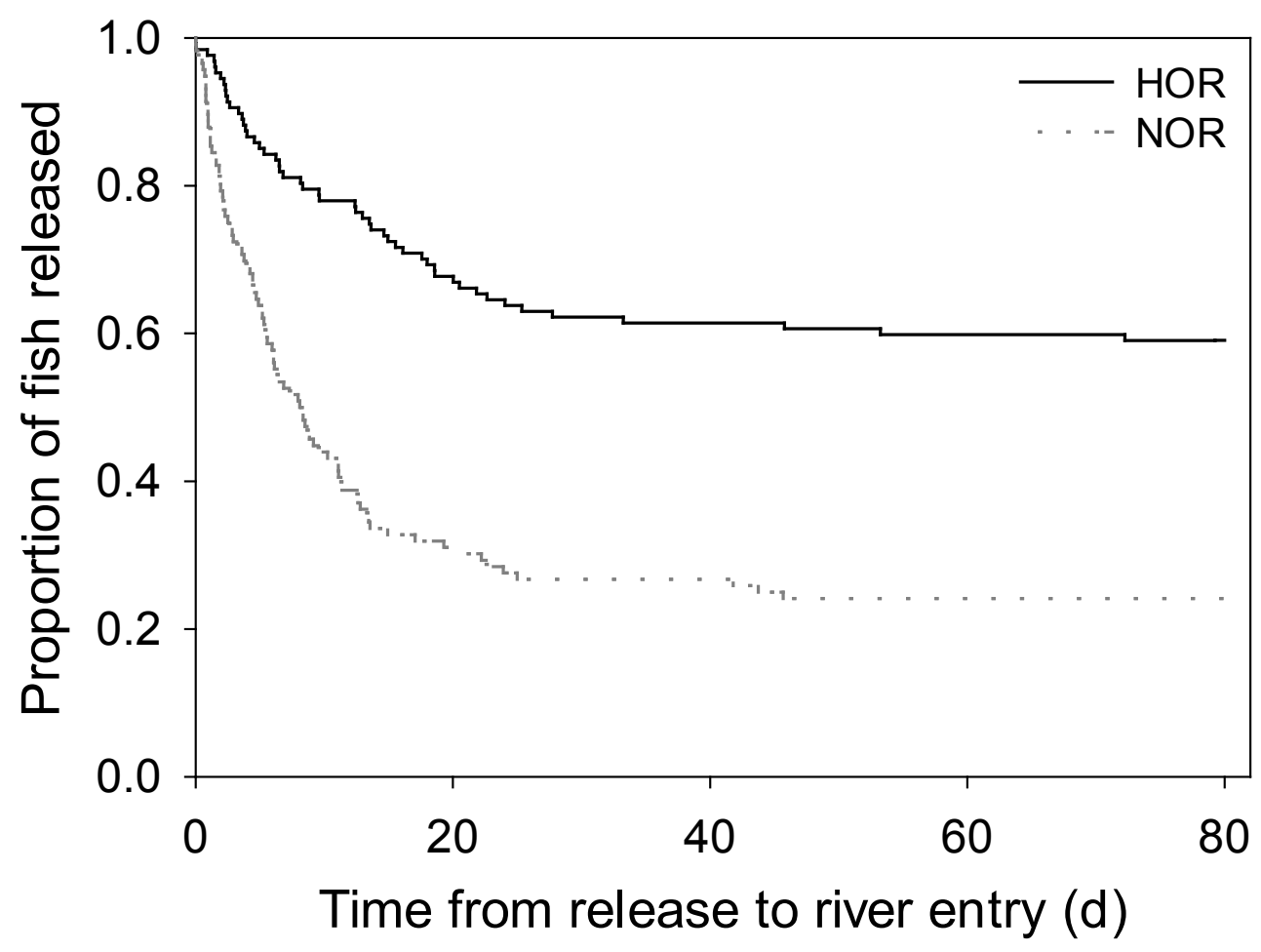

Figure 12. Graph showing survival distribution function of elapsed time from release of radio-tagged adult coho salmon in Lake Scanewa to entry in the Cowltiz River or Cispus River, Washington, 2005-09. Data include hatchery-origin (HOR) and natural-origin (NOR) fish.

\section{Fates}

The largest percentage of HOR coho salmon that were released into Lake Scanewa had reservoir fates while the largest percentage of NOR coho salmon released into Lake Scanewa had Cowlitz River fates. We found that 43.3 percent of the HOR coho salmon released into Lake Scanewa had reservoir fates, followed by Cowlitz River (27.6 percent), fallback (17.3 percent), and Cispus River (11.8 percent) fates (table 21). Conversely, more than one-half of the NOR coho salmon (53.4 percent) that were released into Lake Scanewa had Cowlitz River fates, followed by reservoir (30.2 percent), Cispus River (9.5 percent), and fallback fates ( 6.9 percent). The percentage of HOR coho salmon (17.3 percent) with fallback fates was higher $\left(\chi^{2}=6.09, P<0.01\right)$ than the percentage of NOR coho salmon (6.9 percent), for fish that were released into Lake Scanewa. Although fallback percentages varied by year, HOR fallback exceeded 15 percent during most years whereas NOR fallback was less than 10 percent in all years when coho salmon were studied (table 8 ). We visually assessed the relationship between monthly average discharge and percentage of fallback for monthly release groups of tagged coho salmon that were released into Lake Scanewa. This assessment showed little evidence for a discharge/fallback relationship (fig. 7). 
Most tagged coho salmon that were released into the Cowlitz River or Cispus River remained in those rivers after release (table 21). We found that 85.7 percent of the HOR coho salmon and 100.0 percent of the NOR coho salmon that were released into the Cowlitz River had Cowlitz River fates (table 21). Similarly, 96.9 percent of the HOR coho salmon and 94.1 percent of the NOR coho salmon that were released into the Cispus River had Cispus River fates (table 21). We compared fallback rates between coho salmon that were released into the rivers $(3.7$ percent) against those that were released into Lake Scanewa (12.3 percent) and found that fallback was lower for river-released fish $\left(\chi^{2}=11.4, P\right.$ $<0.0007$; table 21).

Table 21. Number of radio-tagged adult coho salmon assigned to Cowlitz River, Cispus River, Lake Scanewa, and fallback fates, Washington, 2005-09.

[Data are presented for hatchery-origin (HOR) and natural-origin (NOR) fish]

\begin{tabular}{|c|c|c|c|c|c|c|}
\hline \multirow{2}{*}{ Release site } & \multirow{2}{*}{ Origin } & \multirow{2}{*}{ Year } & \multicolumn{4}{|c|}{ Fate } \\
\hline & & & Cowlitz River & Cispus River & Lake Scanewa & Fallback \\
\hline \multirow[t]{5}{*}{ Reservoir } & HOR & 2005 & 45.0 & 5.0 & 50.0 & 0 \\
\hline & & 2006 & 25.9 & 18.5 & 33.3 & 22.2 \\
\hline & & 2008 & 45.2 & 22.6 & 16.1 & 16.1 \\
\hline & & 2009 & 10.2 & 4.1 & 63.3 & 22.4 \\
\hline & & Overall & 27.6 & 11.8 & 43.3 & 17.3 \\
\hline \multirow[t]{4}{*}{ Reservoir } & $\overline{\text { NOR }}$ & 2005 & 58.3 & 8.3 & 27.8 & 5.6 \\
\hline & & 2007 & 49.1 & 10.9 & 30.9 & 9.1 \\
\hline & & 2008 & 56.0 & 8.0 & 32.0 & 4.0 \\
\hline & & Overall & 53.4 & 9.5 & 30.2 & 6.9 \\
\hline \multirow[t]{4}{*}{ Cowlitz River } & HOR & 2006 & 100.0 & 0 & 0 & 0 \\
\hline & & 2008 & 100.0 & 0 & 0 & 0 \\
\hline & & 2009 & 65.1 & 0 & 18.6 & 16.3 \\
\hline & & Overall & 85.7 & 0 & 7.6 & 6.7 \\
\hline Cowlitz River & NOR & 2008 & 100.0 & 0 & 0 & 0 \\
\hline \multirow[t]{4}{*}{ Cispus River } & HOR & 2006 & 0 & 96.0 & 0 & 4.0 \\
\hline & & 2007 & 11.1 & 88.9 & 0 & 0 \\
\hline & & 2008 & 0 & 100.0 & 0 & 0 \\
\hline & & Overall & 1.6 & 96.9 & 0 & 1.6 \\
\hline \multirow[t]{3}{*}{ Cispus River } & NOR & 2007 & 0 & 100.0 & 0 & 0 \\
\hline & & 2008 & 7.7 & 84.6 & 7.7 & 0 \\
\hline & & Overall & 2.9 & 94.1 & 2.9 & 0 \\
\hline
\end{tabular}




\section{Discussion}

This study used radiotelemetry to evaluate responses of adult steelhead, Chinook salmon, and coho salmon to a trap-and-haul program in the upper Cowlitz River Basin. Research on trap-and-haul programs has been fairly limited, but the available information has shown that prespawn mortality and fallback rates can be relatively high, and that spawning success is affected by factors such as sex, origin, and release date (O'Malley and others, 2014; Naughton and others, 2015; Sard and others, 2015). Data collected during this study were insightful for understanding how adult steelhead and salmon move within the upper Cowlitz River Basin following transport and for providing estimates on the proportion of transported fish that remain in the Cowlitz and Cispus Rivers at the onset of the spawning period.

Hatchery-origin and NOR fish had distinctly different behavioral responses to release in the upper Cowlitz River Basin, and these responses were similar for all species that were studied. We found that 38-66 percent of the HOR steelhead, Chinook salmon, and coho salmon that were released into Lake Scanewa eventually moved upstream and entered either the Cowlitz River or the Cispus River, but this was substantially lower than NOR steelhead, Chinook salmon, and coho salmon, which ranged from 76 to 84 percent. Hatchery-origin fish also remained in Lake Scanewa longer than NOR fish before moving upstream. These behavioral differences translated into differences in fish distributions during the spawning period as well. Less than one-half (35-49 percent) of the reservoir-released HOR fish had Cowlitz River or Cispus River fates, whereas most (62-82 percent) of the reservoir-released NOR fish were assigned to one of the river fates during the spawning period. Our results support other studies that have shown that HOR steelhead and salmon are less fit in the wild than NOR steelhead or salmon (Christie and others, 2014; Sard and others, 2015). Although many hypotheses are still being tested regarding the causal mechanisms for this relationship (Hankin and others, 1993; Theriault and others, 2011; Ford and others; 2012; Milot and others, 2013), our data suggest that behavioral differences play a role.

Tagged fish used the Cowlitz River in higher proportions than the Cispus River, and this relationship did not vary by species or origin. Data collected from radio-tagged fish that were released into Lake Scanewa showed that fish were more likely to enter the Cowlitz River than the Cispus River. We found that 67-70 percent of the NOR steelhead and salmon were detected in the Cowlitz River, while only 23-47 of those fish were detected in the Cispus River. The relationship was the same for HOR steelhead and salmon, although the proportion of fish in each river was lower: 23-47 percent of the HOR fish entered the Cowlitz River while 12-38 percent entered the Cispus River. These data show that steelhead and salmon tend to select the Cowlitz River more than the Cispus River, and data from the NOR fish indicate that production is higher in the Cowlitz River. More than one-half of the NOR steelhead and coho salmon (53 percent each) that were released into Lake Scanewa had Cowlitz River fates, as did 38 percent of the NOR Chinook salmon. In contrast, only 29 percent of the NOR steelhead, 24 percent of the NOR Chinook salmon, and 10 percent of the NOR coho salmon had Cispus River fates. This trend will be interesting to follow in the coming years. The reintroduction effort to the upper Cowlitz River Basin has only been in place since the mid-1990s so these relationships could change substantially as steelhead and salmon populations expand throughout the available habitat in the system. 
Tagged fish that were released at the Cowlitz River or Cispus River release sites were less likely to fallback downstream of Cowlitz Falls Dam than fish that were released into Lake Scanewa. Data from the river release sites was less robust than from the reservoir release sites because fewer fish were released in fewer years at those locations. However, the trends in fallback rates from the available data are compelling. Annual estimates of fallback for reservoir-released steelhead and coho salmon often exceeded 10 percent and were greater than 20 percent in some years, whereas fallback estimates for river-released steelhead and coho salmon were less than 5 percent during most years. Fallback estimates were generally highest for Chinook salmon, which typically reside in the upper Cowlitz River Basin for several months prior to spawning. Annual fallback estimates for Chinook salmon often exceeded 15 percent regardless of release site, but within-year comparisons indicate that benefits are possible when river-release sites are used. In 2007, the fallback estimate for reservoir-released HOR Chinook salmon was 45 percent, and the estimates for Cowlitz River and Cispus River releases of HOR Chinook salmon were 18 and 12 percent, respectively. The river release sites also resulted in substantially higher estimates of river fates for tagged steelhead and salmon, particularly those of hatchery-origin. Annual estimates of river fates for steelhead ranged from 8 to 63 percent for reservoir-released fish, while Cowlitz River and Cispus River releases had fate estimates in those rivers that ranged from 67 to 93 percent. The trends generally were the same for Chinook salmon and coho salmon and in several years all river-released coho salmon were assigned a fate of the same river where they were released.

This study showed that substantial losses can occur to populations of adult steelhead and salmon after release in the upper Cowlitz River Basin. During the course of the study, we found that 18-48 percent of the tagged fish (by species and origin) either remained in Lake Scanewa or fell back downstream of Cowlitz Falls Dam. There is little or no spawning habitat in the reservoir and fish that fallback downstream of the dam cannot move back into the upper Cowlitz River Basin because the dam does not have a fish ladder for upstream passage. Therefore, our findings indicate that about one-fifth to one-half of the transported fish failed to move into the Cowlitz River or Cispus River during the spawning period. Similar losses have been documented in other systems. Naughton and others (2015) reported that average prespawn mortality rates during 2009-14 for female Chinook salmon exceeded 60 percent in Fall Creek and were about 30 percent in the North Fork Middle Fork Willamette River, Oregon, following trap-and-haul transport. Studies have also documented significant fallback rates for adult steelhead and salmon that are released upstream of dams. In Foster Reservoir, Oregon, Naughton and others (2015) found that 12 and 23 percent of their tagged Chinook salmon fell back downstream of Foster Dam during 2012 and 2013, respectively. These results demonstrate the importance of conducting evaluations that assess trap-and-haul operations to understand loss rates that occur after fish are released. This study provided baseline information on movement patterns and loss rates, but additional research may be required to improve our understanding of the current status of the reintroduction program in the upper Cowlitz River Basin. 
The fate estimates made in this study provide insights into dispersal and loss patterns in the upper Cowlitz River Basin, but our study design did not directly assess factors such as prespawn mortality, harvest, or spawning success. The telemetry array and mobile tracking methods that were used during this study focused on identifying coarse movement patterns and determining fallback rates in the study area. The results obtained are informative, but estimates of Cowlitz River, Cispus River, and reservoir fates are likely biased because we were not able to assess prespawn mortality, harvest, and spawning success. Cowlitz River and Cispus River fates almost certainly overestimate the proportion of fish that spawn in these rivers because some fish likely died prior to spawning due to natural factors (for example, disease, predation) or harvest by anglers. Additionally, it is unlikely that all fish that survived to the onset of the spawning period were successful at spawning, so the proportion of transported fish that were successful spawners is likely lower than what was estimated using our study design. The estimates of fallback probably are less biased, however, because we were able to detect fish within minutes of their fallback event, and we have a good understanding of when the onset of spawning occurs for each of the species that we studied.

This study provided data that were insightful for understanding behavior and movement patterns of adult salmon and steelhead in the upper Cowlitz River Basin. The research effort yielded estimates of fallback rates and fish fates that may be useful for fishery managers in the years to come. Future research in the upper Cowlitz River Basin may use additional telemetry studies, genetic analyses, and spawning ground surveys to provide additional insights into the progress of the reintroduction effort.

\section{Acknowledgments}

We are particularly grateful to Wade Heimbigner with the Pacific States Marine Fisheries Commission for his efforts with fish tagging, tag recoveries, and mobile tracking during the study. Additionally, we thank Tacoma Power for transporting and releasing all tagged fish during the study. Numerous private landowners throughout the upper Cowlitz River Basin provided access for fixed sites and mobile tracking and we sincerely appreciate their cooperation. Finally, we thank our colleagues at the Columbia River Research Laboratory for their efforts with fieldwork during the study. This document was reviewed by Rachel Reagan and Brady Allen, and revisions based on their comments improved the quality of the final document. 


\section{References Cited}

Allison, P.D., 1995, Survival analysis using SAS-A practical guide: Cary, North Carolina, SAS Institute, Inc., $292 \mathrm{p}$.

Anderson, J.H., Pess, G.R., Carmichael, R.W., Ford, M.J., Cooney, T.D., Baldwin, C.M., and McClure, M.M., 2014, Planning Pacific salmon and steelhead reintroductions aimed at long-term viability and recovery: North American Journal of Fisheries Management, v. 34, p. 72-93.

Brenkman, S.J., Pess, G.R., Torgersen, C.E., Kloehn, K.K., Duda, J.J., and Corbett, S.C., 2008, Predicting recolonization patterns and interactions between potadromous and anadromous salmonids in response to dam removal in the Elwha River, Washington State, USA: Northwest Science, v. 82, p. 91-106.

Bryant, M.D., Frenette, B.J., and McCurdy, S.J., 1999, Colonization of a watershed by anadromous salmonids following the installation of a fish ladder in Margaret Creek, Southeast Alaska: North American Journal of Fisheries Management, v. 19, p. 1,129-1,136.

Christie, M.R., Ford, M.J., and Blouin, M.S., 2014, On the reproductive success of early-generation hatchery fish in the wild: Evolutionary Applications, v. 7, p. 883-896.

Ford, M.J., Murdoch, A.R., and Howard, S., 2012, Early male maturity explains a negative correlation in reproductive success between hatchery-spawned salmon and their natural spawning progeny: Conservation Letters, v. 5, p. 450-458.

Hankin, D.G., Nicholas, J.W., and Downey, T.W., 1993, Evidence for inheritance of age at maturity in Chinook salmon (Oncorhynchus tshawytscha): Canadian Journal of Fisheries and Aquatic Science, v. 50, p. 347-358.

Keefer, M.L., Peery, C.A., Ringe, R.R., and Bjornn, T.C., 2004, Regurgitation rates of intragastric radio transmitters by adult Chinook salmon and steelhead during upstream migration in the Columbia and Snake rivers: North American Journal of Fisheries Management, v. 24, p. 47-54.

Kock, T.J., Perry, R.W., Gleizes, C., Dammers, W., and Liedtke, T.L., 2016, Angler harvest, hatchery return, and tributary stray rates of recycled adult summer steelhead Oncorhynchus mykiss in the Cowlitz River, Washington: River Research and Applications, DOI:10.1002/rra.3032.

Milot, E., Perrier, C., Papillon, L., Dodson, J.J., and Bernatchez, L., 2013, Reduced fitness of Atlantic salmon released in the wild after one generation of captive breeding: Evolutionary Applications, v. 6, p. $472-485$.

National Marine Fisheries Service, 1999, Endangered Species Act 4(d) rules for Pacific salmon and steelhead, Portland, Oregon.

Naughton, G.P., Caudill, C.C., Clabough, T.S., Keefer, M.L., Knoff, M.L., Morasch, M.R., Brink, G.A., Blubaugh, T.J., and Jepson, M.A., 2015, Migration behavior and spawning success of spring Chinook salmon in Fall Creek, the North Fork Middle Fork Willamette and Santiam Rivers-Relationships among fate, fish condition, and environmental factors, 2014: Report by the University of Idaho for the U.S. Army Corps of Engineers, Portland, Oregon.

O’Malley, K.G., Evans, M.L., Johnson, M.A., Banks, M.A., Jacobson, D., and Hogansen, M., 2014, Genetic parentage analysis of spring Chinook salmon on the South Santiam River-Insights into population productivity and reintroduction strategies: Report by the Oregon Department of Fish and Wildlife for the U.S. Army Corps of Engineers, Portland, Oregon.

Pearsons, T.N., and Temple, G.M., 2007, Impacts of early stages of salmon supplementation and reintroduction programs on three trout species: North American Journal of Fisheries Management, v. 27, p. $1-20$. 
Sard, N.M., O’Malley, K.G., Jacobson, D.P., Hogansen, M.J., Johnson, M.A., and Banks, M.A., 2015, Factors influencing spawner success in a spring Chinook salmon (Oncorhynchus tshawytscha) reintroduction program: Canadian Journal of Fisheries and Aquatic Sciences, v. 72, 1,390-1,397.

Serl, J.D., and Morrill, C., 2010, Summary report for the 1996 to 2009 seasonal operation of the Cowlitz Falls fish facility and related Cowlitz Falls anadromous reintroduction program activities: Report by the Washington Department of Fish and Wildlife to the Bonneville Power Administration, $195 \mathrm{p}$. Sokal, R.R., and Rohlf, J.F., 1996, Biometry: New York, W.H. Freeman and Company, 887 p.

Theriault, V., Moyer, G.R., Jackson, L.S., Blouin, M.S., and Banks, M.A., 2011, Reduced reproductive success of hatchery coho salmon in the wild-Insights into most likely mechanisms: Molecular Ecology, v. 20, p. 1,860-1,869. 
Publishing support provided by the U.S. Geological Survey

Science Publishing Network, Tacoma Publishing Service Center

For more information concerning the research in this report, contact the Director, Western Fisheries Research Center U.S. Geological Survey

6505 NE 65th Street

Seattle, Washington 98115

http://wfrc.usgs.gov/ 


\section{密}

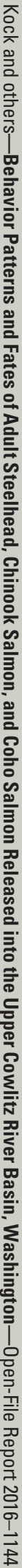

ISSN 2331-1258 (online)

http://dx.doi.org/10.3133/ofr20161144 